\title{
The Chemistry and Pharmacology of Fungal Genus Periconia: A Review
}

\author{
Azmi Azhari ${ }^{1,2}$ and Unang Supratman 1,3,* \\ 1 Department of Chemistry, Faculty of Mathematic and Natural Sciences, Universitas Padjadjaran, \\ Jatinangor 45363, Indonesia; azmi@syekhnurjati.ac.id \\ 2 Department of Chemistry Education, Faculty of Tarbiyah and Teacher Training, Institut Agama Islam Syekh \\ Nurjati, Cirebon 45132, Indonesia \\ 3 Central Laboratory, Universitas Padjadjaran, Jatinangor 45363, Indonesia \\ * Correspondence: unang.supratman@unpad.ac.id
}

check for updates

Citation: Azhari, A.; Supratman, U. The Chemistry and Pharmacology of Fungal Genus Periconia: A Review. Sci. Pharm. 2021, 89, 34. https:// doi.org/10.3390/scipharm89030034

Academic Editor: Helen D. Skaltsa

Received: 19 May 2021

Accepted: 5 July 2021

Published: 29 July 2021

Publisher's Note: MDPI stays neutral with regard to jurisdictional claims in published maps and institutional affiliations.

Copyright: (c) 2021 by the authors. Licensee MDPI, Basel, Switzerland This article is an open access article distributed under the terms and conditions of the Creative Commons Attribution (CC BY) license (https:// creativecommons.org/licenses/by/ $4.0 /)$
Abstract: Periconia is filamentous fungi belonging to the Periconiaceae family, and over the last 50 years, the genus has shown interest in natural product exploration for pharmacological purposes. Therefore, this study aims to analyze the different species of Periconia containing natural products such as terpenoids, polyketides, cytochalasan, macrosphelides, cyclopentenes, aromatic compounds, and carbohydrates carbasugar derivates. The isolated compound of this kind, which was reported in 1969, consisted of polyketide derivatives and their structures and was determined by chemical reaction and spectroscopic methods. After some years, 77 compounds isolated from endophytic fungus Periconia were associated with eight plant species, 28 compounds from sea hare Aplysia kurodai, and ten from endolichenic fungi Parmelia sp. The potent pharmacological agents from this genus are periconicin A, which acts as an antimicrobial, pericochlorosin B as an anti-human immunodeficiency virus (HIV), peribysin $\mathrm{D}$, and pericosine $\mathrm{A}$ as cytotoxic agents, and periconianone $\mathrm{A}$ as an antiinflammatory agent. Furthermore, information about taxol and piperine from Periconia producing species was also provided. Therefore, this study supports discovering new drugs produced by the Periconia species and compares them for future drug development.

Keywords: natural product diversity; Periconia; Periconiaceae; pharmacological activities

\section{Introduction}

Periconia is filamentous fungi belonging to the Periconiaceae Family (Ascomycetes), and according to Index Fungorum [1], there are 202 epithets with 12 varieties. However, only 40 species of the Periconia genus are currently recognized [2-4]. This genus has spread as endophytes and saprobes in plants with multiple habitats and has been shown to be plant pathogens. Leukel [5] reported that Milo disease, found in crops, can be caused by one species of Periconia, P. circinata (L. mangin). Interestingly, these fungi can live in the gastrointestinal tract of animals [6] and as an endolinchenic fungus [7-9].

Over the past 50 years, Periconia has become an exciting resource for natural product research because it produces many bioactive secondary metabolites. This genus is reported to have tremendous activities as antimicrobial, anti-human immunodeficiency virus (HIV), potent cytotoxicity, and anti-inflammatory agents from many groups of secondary metabolites, which include terpenoid, meroterpene, polyketide, cytochalasan, macrolide, macropshelide, aromatic compound, and carbohydrate derivates [6-14].

The study has been reported in at least two main areas: (1) chemical and bioactivities studies of the isolated secondary metabolites from different species of fungi and various host origins. The species produce secondary metabolites with multiple biosynthesis pathways. (2) Molecular and genomic studies for species identification and revised genus annotation. A comprehensive review of the Periconia fungal genus for chemical content and its pharmacological aspects between these studies has not been conducted. 
Since 1969, more than a hundred bioactive secondary metabolites of the genus Periconia have been discovered. Interestingly, study communities have gained more attention for Periconia since the fungus reportedly produces Taxol (anticancer agent) [15] and also Piperine (antimycobacterial agent) [12]. For this significant interest, the potential of Periconia species producing secondary metabolites was explored. This highlights chemical contents from different strains classified by the natural products group and with particular emphasis on their pharmacological activities. Furthermore, the parts and origin, function, and biological roles were detailed. All databases with the keyword "periconia" from search engines Scopus, Scifinder, PubMed, and Google Scholar were obtained from May 1969 to October 2020. This study should be helpful in the discovery of new drugs in the future.

\section{Phylogeny of the Genera Periconia}

The genus Periconia was first introduced in 1791 by H. J. Tode, namely P. lichenoides Tode ex Mérat [2]. Periconia is classified as a member of the Family Periconiaceae and separated from Massarineae as a sister taxon because of distinct phylogeny [16]. In addition, the phylogenetic tree is Kingdom Fungi, Phylum Ascomycota, Subphylum Pezizomycotina, Class Dothideomycetes, Subclass Pleosporomycetidae, Order Pleosporales, Family Periconiaceae, and Genus Periconia [1,16-18].

Periconia has macronematous conidiophores with pale to dark brown, branched or unbranched, smooth or verruculose. Conidia cells are spherical, aseptate, catenate or solitary, smooth or verruculose, pale to dark brown. The conidiogenous cells are monoblastic or polyblastic, integrated or discrete, ovoid to clavate formed on the terminal or intercalary of the stipe [2]. This genus is registered on Index Fungorum and Mycobank with Registration Identifier (ID): 9263 and The National Center for Biotechnology Information (NCBI) taxonomy browser with ID: 97971 [1,16-18].

\section{Natural Product Diversity}

\subsection{Overview of Compounds Derived from the Periconia Fungus}

From 1969 to 2020, a total of 104 compounds were isolated from Periconia. Terpenes are the major classes of naturally occurring secondary metabolites from the Periconia genus comprising a total of 43 terpenoids (41.3\%). Furthermore, there are 40 polyketides $(38.4 \%)$ : 11 cytochalasans, 1 macrolide, 10 macrosphelides, 4 cyclopentes, and 14 other polyketides. There are 14 aromatic compounds (13.4\%) and 5 carbohydrates (4.8\%) which were isolated from the Periconia genus. The other compounds, taxol and piperine, which its plant host originally produced, this fungus also reportedly made.

Periconia compound endophytic fungi in eight plant species: Annona muricata (42 compounds), Taxus cuspidata (2 compounds), Xylopia aromatica (2 compounds), Thysanoleana latifolia (2 compounds), Sorghum bicolor (5 compounds). Rosa chinensis (1 compound), Piper longum (1 compound), and terrestrial herbaceous plants (4 compounds). Endosymbionts gastrointestinal sea hare A. kurodai (28 compounds), and endolichenic fungi Parmelia sp (10 compounds) also form part of Periconia. These compounds are summarized in Table 1 by type of compounds, molecular weight (MW) and mass spectrometry (MS) data, strain type, various host and origins.

\subsection{Taxol and Piperine Producing Periconia Species}

Taxol or paclitaxel (1) are well-known anticancer drugs with a tetracyclic diterpenoid structure (Figure 1). Initially, its small quantity was obtained from ethanol extract of the bark of Taxus brevifolia) [19]. The amount was only $0.01-0.03 \%$ dry weight and this is a significant factor contributing to its high price. This problem is emerging in the scientific community to investigate another source of the compound. 

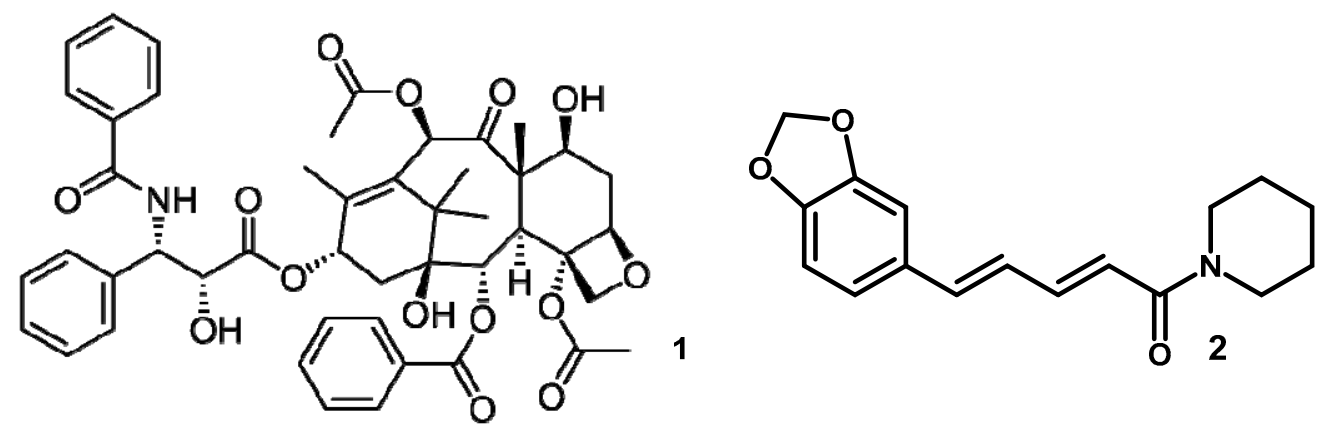

Figure 1. The chemical structure of taxol (1) and piperine (2) from the Periconia genus.

The discoveries continued with this development, and Stierle et al. [20] found that the fungal endophytes of Taxomyces andreanae in the Pacific region can produce Taxol like the host. On the contrary, Li et al. [15] studied fungal endophytes of Torreya grandifolia, when taxol is not synthesized.

Furthermore, Periconia from this plant was demonstrated unequivocally for taxol production by a semi-synthetic medium. The fungi were fermented with a special medium through an activator of metabolism. Several compounds studied include serinol, $p$ hydroxybenzoic acid, and a mixture of phenolic acids. Benzoic acid, known as not a taxol precursor, activates taxol production metabolism in Periconia. This was conducted at $0.01 \mathrm{mM}$ with the best yield concentration $831 \pm 27 \mathrm{ng} \mathrm{L}^{-1}$ through spectroscopic and immunological methods.

According to Verma et al. [12], Periconia can also produce compounds similar to its host. For example, Piperine (2), an alkaloid (Figure 1) with many pharmacological activities obtained from the ethanol extract of fruits Piper longum (only consist 3-5\% dry weight basis), also being produced by Periconia. The 2 were obtained from ethyl acetate extract after four weeks of fermentation on a potato dextrose broth. The isolated 2 then crystallized, elucidated by single-crystal X-ray crystallography, and studied extensively as an antimycobacterial agent. These piperidine derivates (2) were treated for multidrug-resistant Mycobacterium tuberculosis and an atypical mycobacterium $M$. smegmetis with a Minimum Inhibitory Concentration (MIC) 1.74 and $2.62 \mu \mathrm{g} / \mathrm{mL}$ (strong activity), respectively, (control positive or negative are not included). In this context, the scientific community increased interest in natural product exploration from endophytic fungi and other fungal sources, especially for the Periconia genus.

\subsection{Terpenoids}

Some species of Periconia appear to produce terpenoids and have engaging pharmacological activities. According to Bach and Rohmer [21], the starting unit of terpenoid is from the five-carbon precursor unit, isopentenyl diphosphate (IPP), and dimethylallyl diphosphate (DMAPP). This is continued with a head-to-tail condensation repetitive reaction of IPP and DMAPP with prenyltransferases. These produce prenyl diphosphates of increasing length: geranyl-, farnesyl-, geranylgeranyl-diphosphate that lead to synthesizing the different isoprenoids and products. There are thirty-nine terpenoid compounds isolated from this genus. This includes six monoterpenoids (carene and menthene-types), two diterpenoids (fusicoccane-type), twenty-five sesquiterpenoids (cadinane, and eremophilane-types), one norsesquiterpenoid, one meroterpene (diterpenoid alkaloid), and one steroid.

Six monoterpenoids were obtained from the Periconia sp. F-31, and they live inside the leaves of $A$. muricata as an endophyte. Furthermore, broth extract of this fungus led to isolation of three new 2-carene derivatives: 2-carene-5,8-diol (3), 2-carene-8,10-diol (4), 2-carene-8-acetamide (5), one new menthene-type: 8-hydroxy-1,7-expoxy-2-menthene (6). Other derivatives include one known monoterpenes, anethofuran (7) [22], and a new carene-type: (-)-(1R,4R,6S,7S)-2-caren-4,8-olide (8) [23].

Carene-types monoterpenoid (3) was determined using a combination of 1D, 2D Nuclear Magnetic Resonance (NMR) with ${ }^{1} \mathrm{H}-{ }^{1} \mathrm{H}$ Homonuclear Correlation Spectroscopy 
(COSY), Heteronuclear Multiple Bond Correlation (HMBC), and Nuclear Overhauser Effect Spectroscopy (NOESY). Additionally, the absolute configuration was calculated with the Time Dependent-Discrete Fourier Transform (TD-DFT) method at the B3LYP/6-31G(d) level. There are two stereoisomers of relative configuration $(1 R, 5 R, 6 S, 7 S)$ and $(1 S, 5 S, 6 R, 7 R)$, which were determined using experimental electronic circular dichroism (ECD). Another two carene-type monoterpenoids (4-5) were determined by 1D NMR spectra. This was because of the nearly identical structure feature of 3, confirmed with HMBC correlation, and The Nuclear Overhauser Effect Difference (NOEDIFF) experiments. Meanwhile, $\mathbf{6}$ was determined by menthene-type monoterpenoids using the same method. The configuration of 8 was assigned by the NOE difference and circular dichroism (CD) spectroscopic data. CD spectrum confirmed exhibited positive and negative Cotton effect $(203 \mathrm{~nm})$ and $(228 \mathrm{~nm})$ supporting the $1 R, 4 R, 6 S, 7 S$ configuration.

These five monoterpenoids (3-6, 8), biogenetically share usual intermediate cation (methyl $/ \alpha$-terpinyl), then cyclization by monoterpene synthases (non specific) to produce disimillar structural types (carene and menthene) [22]. Furthermore, 2-carene was transformed to 8 through a series of oxidation and lactonization [23]. Monoterpenoids play an essential role in plants' resistance to high temperatures and increase heat stress (photosynthetic device) [24].

Diterpenoid from Periconia was reported in 2004, and it isolated periconicins A (9) and B (10) from Periconia sp. This was obtained from the small inner branches of T. cuspidata Kangwon Region of Korea [25]. The chemical structure of both compounds was determined by 1D, 2D NMR $\left({ }^{1} \mathrm{H}^{-}{ }^{1} \mathrm{H}\right.$ COSY, Heteronuclear Multiple Quantum Coherence HMQC, HMBC, and NOESY), Infra-Red (IR) Spectra and High-Resolution Electron Ionization Mass Spectrometry (HREIMS) techniques. In addition, Periconicin B (10) was also isolated from $P$. atropurpurea, the endophytic fungi from $X$. aromatica leaves [11]. The structure of both compounds has the same carbon structure as the fusicoccins [25]. These fusicoccins are the first member of a group called fusicoccanes with a dicyclopenta[a,d]cyclooctane ring system and isolated from the phytopathogenic fungi Fusicoccum amygdali [26]. The compounds are reportedly found in fungi, insects, and plants. Fussiococcins are a plant growth regulator for the elongation mechanism, promoting the opening of the leaf stomata, root inducing formation, and fast seed germination [27].

Further studies should be conducted with Periconia to produce sesquiterpenes, a 15carbon-length natural product that is synthesized by sesquiterpene synthase from farnesyl pyrophosphate [27]. The reaction continues with the cyclic carbocation undergoing further cyclization and rearrangement until the active site is extinguished [28,29]. In addition, eremophilane and cadinane-types are isolated from strains of Periconia. Eremophilanetypes possessed contradiction with isoprene rules head-to-tail linkages with a biological role for phytotoxic, phytohormonal and mycotoxic for protection [30].

Yamada and his co-worker isolated eremophilane terpenes called peribysin from the strain P. byssoides OUPS-N133, which lives in gastrointestinal sea hare A. kurodai. This strain was fermented in $90 \mathrm{~L}$ medium of malt extract $1 \%$, glucose $1 \%$, and peptone $0.5 \%$ with artificial seawater with $\mathrm{pH}$ adjusted to 7.5 in 4 weeks. Peribysins A-J (11-20) were isolated from ethyl acetate extract of culture filtrate [13,31-33].

The peribysins were examined extensively with NMR technique such as COSY, HMBC, Distortionless Enhancement by Polarization Transfer (DEPT), and NOESY and mass spectrum for relative configuration. The absolute stereochemistry of these compounds was studied years later. In 2020, Athawale et al., conducted a stereochemical revision of peribysins A (11), B (12), C (13), F (16), and G (17), guided by enantiospecific total synthesis starting from (+)-nootkatone. The synthesis highlight of enone transposition and kinetic iodination results in diastereomers separation [34]. The structure of peribysin D (14) was revised to 6b,13-epoxy-7(11)-eremophilen-8a,12-diol (14) with the Canonical-representation of Stereochemistry (CAST)/CNMR system, and NOE data [35]. Meanwhile, the absolute configuration of peribysin E (15) was revised by Angeles et al., [36]. This was conducted with natural and non-natural enantiomers obtained from $(R)$ - or $(S)$-carvone, respectively, 
and was supported with reinvestigation by Inose et al. [37] through time-dependent DFTbased ECD spectral calculations. Peribysins H (18), I (19), J (20) have an absolute stereo structure base upon spectroscopic analyses using 1D and 2D NMR techniques. This was conducted through some chemical transformations, including the modified Mosher's method [32,33].

Further isolation of peribysins from Periconia was conducted by Inose et al., [37], where it was shown that peribysins $\mathrm{O}-\mathrm{Q}$ (21-23) were obtained from the $P$. macropinosa terrestrial herbaceous plant Kanagawa in 2018. The relative structures elucidate with a quantitative NOE experiment. The absolutes structures of $\mathbf{2 1}$ and $\mathbf{2 2}$ were obtained using the modified Mosher's method and 23 with the ECD exciton coupling theory. Additionally, theoretical ECD calculations were conducted for 21-23 [37]. Reconfirmation of peribysin $Q$ absolute structures were performed by Athawale et al., [34] through enantiospesific total synthesis from (+)-nootkatone.

Another eremophilane sesquiterpene, namely periconianones and endophytic fungi, is isolated from Periconia sp. F-31 and leaves of A. muricata. Zhang et al. [38] isolated periconianone A (24) and B (25), which are polyoxygenated sesquiterpenoid with a new 6/6/6 tricarbocyclic structure. Both structures and absolute configurations were elucidated with extensive spectroscopic analyses, calculated ECD, and single-crystal X-ray diffraction $(\mathrm{Cu} \mathrm{K} \alpha)$. Two years later, Liu et al. [39] isolated periconianones $\mathrm{C}-\mathrm{K}$ (26-34), where $C$ reportedly contained a linkage of $-8 / C-11$ and a 7,12-epoxy moiety. All compounds were elucidated through extensive spectroscopic data analysis, electronic circular dichroism, $\mathrm{Mo}_{2}(\mathrm{AcO})_{4}$-induced circular dichroism, and single-crystal X-ray diffraction $(\mathrm{Cu} \mathrm{sK} \alpha)$. From the same fungus, Ge et al., [23] isolated (+)-(3S,6S,7R,8S)-periconone A (35), and its structure was determined based on extensive spectroscopic data and circular dichroism (CD) exciton chirality for absolute configuration. Furthermore, norsesquiterpenoid, dihydronaphthalene-2,6-dione (36) were isolated from the endophytic fungus Botryosphaeria rhodina [38].

Cadinane-type sesquiterpenoid from Periconia that was firstly reported by Wu et al., [8] is pericoterpenoid A (37), and is an isolate of Periconia sp. (No. 19-4-2-1) obtained from a lichen Parmelia sp. The relative structure determines by the spectroscopic data (IR, MS, 1D- and 2D-NMR) is known as 14-hydroxycadalen-15-oic acid (24). Cadinane-types sesquiterpenes have 1,7-dimethyl-4-isopropyldecaline structure, presume has biogenesis cyclization pathway of bisabolane or germacrane cation or a 2-cis-6-cis-farnesyl precursor [40]. This type of compound has a biological role in defence responses after being attacked by herbivores, fungal and bacterial infections [41]. For this exciting defence mechanism, cadinane-type sesquiterpene was developed for fungicides in the future [8].

Ergosterol such as periconiastone A (38) was also obtained from Periconia sp. which was collected from the leaves of $R$. chinensis [42]. This steroid compound had an unprecedented pentacyclo-[8.7.0.01,5.02,14.010,15]-heptadecane system. With the ECD spectrum, it allows an explicit assignment of the absolute configuration as $4 R, 5 R, 8 R, 9 R, 10 R, 13 R, 14 S, 17 R$, $20 R, 24 R$. From the biosynthetic study, this compound showed a vinylogous $\alpha$-ketol rearrangement and an aldol condensation reaction as crucial steps for its formation [42].

Several compounds from Periconia have hybrid structural molecules as meroterpenes. This chemical investigation showed a class of diterpenoid alkaloids, where pericolactines A$\mathrm{C}$ (36-38), the first nitrogen-containing fusicocccane diterpenoids are isolated from Periconia sp. (No. 19-4-2-1) endolichenic fungus Parmelia sp. Furthermore, the structures of 39-41 and their absolute configurations were determined by spectroscopic analyses and quantum chemical ECD calculation. These compounds represent an unusual 5-5-8-5 tetracyclic ring system. The systems were derived from geranylgeranyl diphosphate (GGDP) and serine conjugated biosynthesis. They belong to the atypical diterpenoid alkaloids [7]. Meanwhile, another hybrid molecule meroterpenes namely periconones B-E (42-45) were isolated from EtOAc extract Periconia sp. F-31 through semi-preparative HPLC. Their structures and absolute configurations were established by extensive spectroscopic data analysis and electronic circular dichroism (ECD). It was suggested that these hybrids are derived 
from typical polyketide-terpenoid pathways formed from one acetyl-CoA starter and five malonyl-CoA extenders coupled with one C5 unit [43]. A summary of the number and types of terpenoids obtained is demonstrated in Table 1. Meanwhile, Figures 2 and 3 showed the structure of the terpenoids compounds.
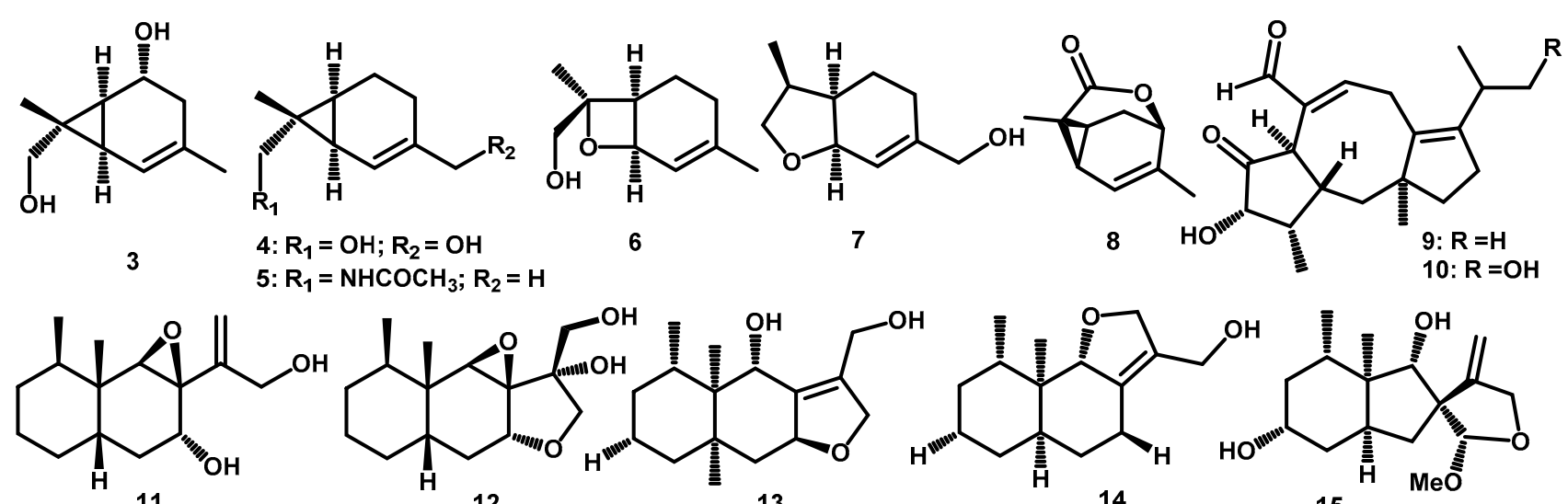

14

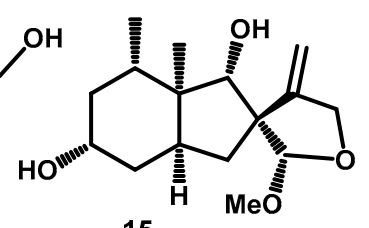

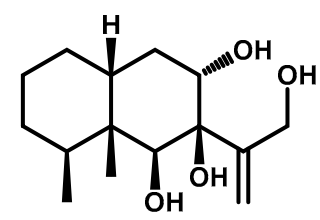

16

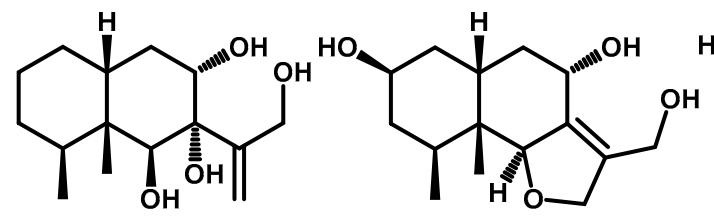

17

18<smiles>CC1C[C@H](O)C[C@H]2C[C@@H]3OCC(CO)=C3[C@@H](O)[C@]12C</smiles>

19
15

Figure 2. The chemical structures of terpenoids 3-20 from the Periconia genus.

\subsection{Polyketides}

Polyketides are a secondary metabolites group with a large diverse structure derived from the poly- $\beta$-keto chain $[44,45]$. They are biosynthesized from acyl-CoA thioesters and undergo repetitive Claisen condensation reactions catalyzed by polyketide synthases (PKSs), which are homologous to fatty acid synthases (FASs) [46]. These compounds are usually used as pharmaceutical agents due to their antibacterial, antifungal, immunosuppressive and antitumor properties [44]. Moreover, polyketides can be produced from diverse microorganisms such as Periconia. Twenty twenty-one polyketide compounds were isolated from Periconia, including ten cytochalasans and eleven other polyketide derivatives.

Polyketides from Periconia genus are isolated from the same natural source known as A. muricata. The first were periconiasin compounds, which as a cytochalasan group play a role in fungi and plants to compete and act as an inhibitor of spore germination, hyphal growth, and sporulation of $B$. cinerea [47]. These compounds were also known as a group of polyketide synthase-nonribosomal peptide synthetase (PKS-NRPS) hybrid metabolites. Periconiasins A-C (46-48) (Figure 4) were first isolated with the 9/6/5 tricyclic ring system [48], and their structures were determined using ${ }^{1} \mathrm{H}-\mathrm{NMR},{ }^{13} \mathrm{C}-\mathrm{NMR}, \mathrm{DEPT}, \mathrm{HMBC}$, ${ }^{1} \mathrm{H}^{-}{ }^{1} \mathrm{H}$ COSY, HSQC, and IR spectroscopic data. Furthermore, the absolute configuration of 46 was determined using single-crystal X-ray diffraction data, which yielded $3 S, 4 R, 5 S, 8 S$, $9 S$, and $17 S$ configurations. In addition, the circular dichroism (CD) spectrum confirmed the negative Cotton effect at $301.5 \mathrm{~nm}$ for 39, $296 \mathrm{~nm}$ for 47, and $294 \mathrm{~nm}$ for 48, where the $n$ $\rightarrow \pi^{*}$ transition indicates the $9 S$ configuration for 46-48. A comprehensible explanation for the unprecedented ring system was supported by the proposed biosynthesis, which occurs from the attachment of an unusual seven acetate/malonate polyketide backbone to one leucine moiety. This was conducted by PKS-NRPS, followed by Diels-Alder and other reactions [48]. 


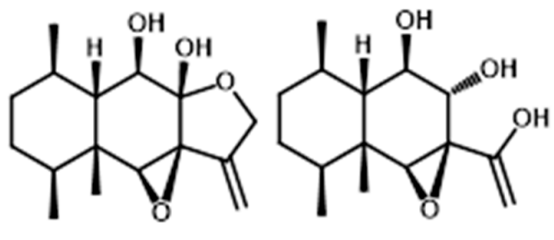

21<smiles>CC(C(=O)O)[C@]1(C)CC2(C)C(=CC1=O)C=CC(=O)[C@H]2C</smiles>

26<smiles>C=C(OC1C=CC2=CC(O)[C@@H](O)CC2(C)C1C)[C@H]1CC2(C)C(=C[C@H](O)C(O)C2C)C(O)[C@H]1O</smiles><smiles>C=C(CO)C1=CC2(C)C(=C(O)C1=O)CCCC2C</smiles>

23<smiles>CC(C)c1ccc(CO)c2ccc(C(=O)O)cc12</smiles><smiles>C[C@@H]1C[C@]2(C)[C@](C)(C(=O)C=CC3=CC(=O)C[C@]32C)[C@@H]1O</smiles>

25
32<smiles>CC(C)=CC[C@H]1C(=O)C2=C(COCCC2O)[C@@H](O)[C@@H]1O</smiles>

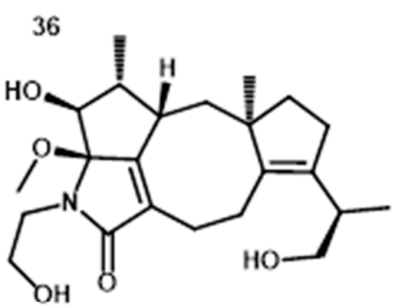

41<smiles>C[C@H]1C(=O)C=CC2=CC(=O)C(O)=C[C@]21C</smiles>
37<smiles>C=C(C)C1(O)CC2(C)C(=CC1O)C=CC(=O)C2C</smiles>

28<smiles>C=C(C)[C@]1(O)C[C@]2(C)C(=C[C@H]1O)C=CC(=O)[C@H]2C</smiles>

29<smiles>CC1C(=O)CC2O[C@]23C[C@@]2(O)OC[C@H](C)[C@@]2(O)C[C@]13C</smiles>

30<smiles>CC1C(=O)C=CC2=C[C@H](O)[C@H](O)CC21C</smiles>

33<smiles>C=C1C=CC2=CC(O)[C@H](O)CC2(C)[C@H]1C</smiles><smiles>C=C1C=CC2=C[C@H](O)C(O)CC2(C)[C@H]1C</smiles>

35

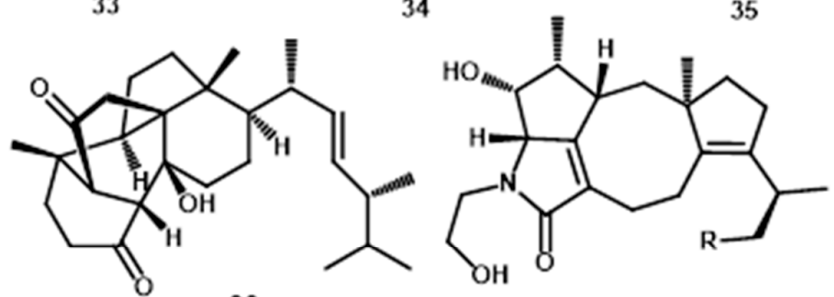

39: $\mathrm{R}=\mathrm{OCOCH}_{3}$<smiles>C/C=C/C=C/C1=C(CO)[C@@H](O)[C@H](O)[C@H](CC=C(C)C)C1=O</smiles><smiles>CC(C)=CC[C@H]1C(=O)C2=C(CO[C@@H]2/C=C/C(C)O)[C@@H](O)[C@@H]1O</smiles>

HO

Figure 3. The chemical structures of terpenoids 21-45 from the Periconia genus.

Further periconiasin compounds sharing the same $9 / 6 / 5$ tricyclic ring system were obtained, and to this context, periconiasins D-F (49-51) was isolated [49]. Their structures were elucidated using ${ }^{1} \mathrm{H}-\mathrm{NMR},{ }^{13} \mathrm{C}-\mathrm{NMR}, \mathrm{DEPT}, \mathrm{HMBC},{ }^{1} \mathrm{H}-{ }^{1} \mathrm{H}$ COSY, and HSQC spectroscopic data. The absolute configuration of $\mathbf{4 9}$ was established by ECD calculations and single-crystal X-ray diffraction analyses assigned as $3 S, 4 R, 5 S, 8 S, 9 S, 14 R, 15 S, 17 R, 19 S$ configuration (50). Meanwhile, periconiasins G-J (52-55) were separated in 2016 [14,50,51]. Their structures were determined using several spectroscopic data analyses, including IR spectra, ${ }^{1} \mathrm{H}-\mathrm{NMR},{ }^{13} \mathrm{C}-\mathrm{NMR}$, DEPT spectra, ${ }^{1} \mathrm{H}-{ }^{1} \mathrm{H}$ COSY, HMBC, and NOESY. The structure of 52 possesses a rare sulfoxide group based on strong absorption at $1028 \mathrm{~cm}^{-1}$ in its IR spectra [14]. In addition, the calculated and experimental ECD curves, which resulted in the absolute configuration of 53 was $3 S, 4 R, 7 R, 8 R, 9 R, 17 S$ [50]. Two periconiasins with another unprecedented ring system were reported, and their structures were established as a $7 / 6 / 5$ tricyclic ring system of periconiasin $G(54)$ and $5 / 6 / 6 / 5$ tetracyclic ring system of periconiasin J (55) [14,51]. 


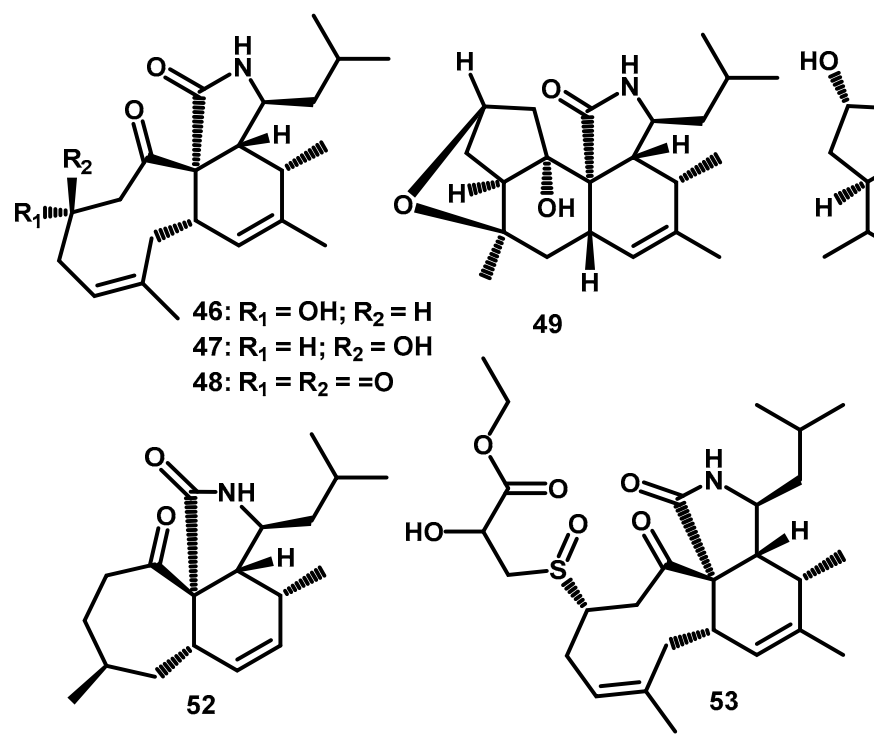

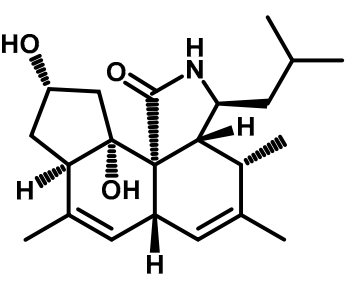

50

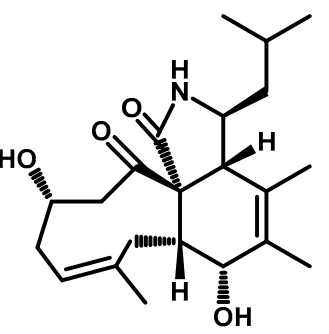

54

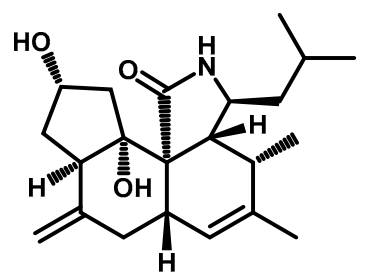

51<smiles>CC1=C[C@H]2C=C(C)[C@H]3CC=C[C@]3(C(=O)NC2CC(C)C)[C@H](O)C1</smiles>

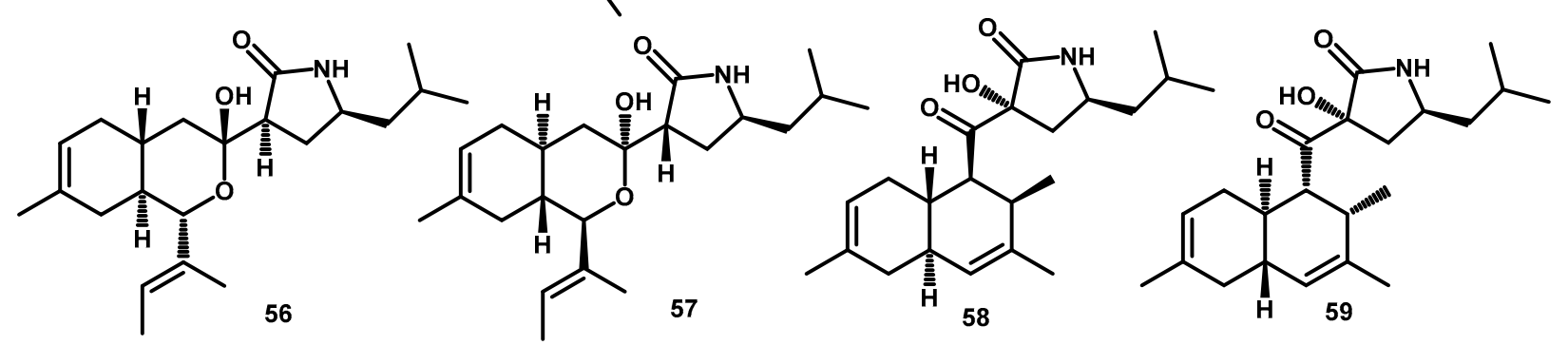

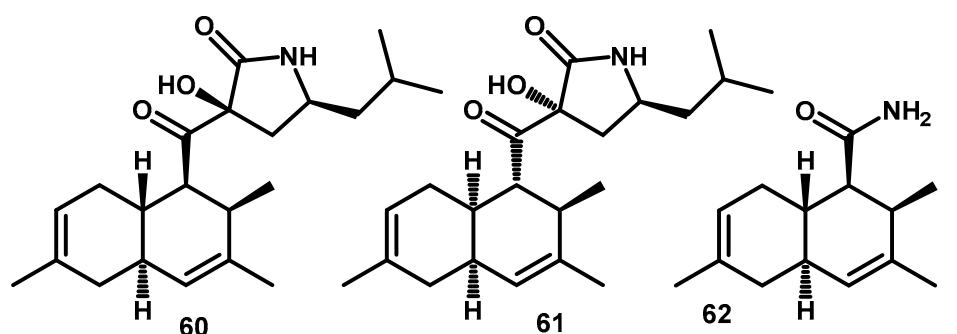<smiles>COc1cc(O)c2c(c1Cl)CC(C)OC2=O</smiles><smiles>CC1Cc2cc(O)cc(O)c2C(=O)O1</smiles><smiles>COc1cc(O)c2c(c1)CC(C)OC2=O</smiles>

Figure 4. The chemical structures of polyketides 46-65 from the Periconia genus.

Many PKS-NRPS compounds that represent the new carbon skeleton have been reported. Additionally, pericoannosin A (56), bearing an unusual hexahydro- $1 \mathrm{H}$-isochromen5-isobutylpyrrolidin-2-one structure was isolated from endophytic fungi Periconia sp. F31 [49]. Elucidation of the structure was conducted using ${ }^{1} \mathrm{H}-\mathrm{NMR},{ }^{13} \mathrm{C}-\mathrm{NMR}, \mathrm{DEPT}$, $\mathrm{HMBC},{ }^{1} \mathrm{H}_{-}{ }^{1} \mathrm{H}$ COSY, and HSQC spectroscopic data. The absolute configuration was established by ECD calculations and single-crystal X-ray diffraction analyses assigned as $2 S, 3 R, 5 R, 10 S, 11 S, 16 S$ [49]. This compound has a similar biosynthetic precursor with periconiasin, which shares the same aminoaldehyde intermediate. However, this pericoannosin has a different route, which underwent the Claisen and hemiacetal reaction to subsequently yield the pericoannosin A $[49,51]$.

Meanwhile, pericoannosin B (57) was isolated in 2016 from the same source and it is known to be the stereoisomer of pericoannosin A (56) [52]. According to Zhang et al., [52], the non-stereoselective Claisen reaction and hemiacetal reaction led to the yield of stereoisomer pairs. The structure of $\mathbf{5 7}$ was determined with extensive spectroscopic analysis of hexahydro$1 H$-isochromen-5-isobutylpyrrolidin-2-one structure skeleton. Meanwhile, the absolute configuration was determined using CD spectra analysis to yield $2 R, 3 S, 5 S, 10 R, 11 R, 16 S$ [52]. 
Subsequently, the investigation for the pericoannosins that was guided by a biosynthetic hypothesis led to the isolation of pericoannosins C-F (58-61) [51]. In this case, Fan et al. [51] proposed the possibility of another Diels-Alder reaction which was conducted by different pairs of conjugated diene and double bond from the same precursor of pericosins and pericoannosins. Their structures were elucidated using ${ }^{1} \mathrm{H}-\mathrm{NMR},{ }^{13} \mathrm{C}-\mathrm{NMR}, \mathrm{DEPT}$, HSQC, HMBC, ${ }^{1} \mathrm{H}^{-}{ }^{1} \mathrm{H}$ COSY, and NOESY spectroscopic data. The absolute configurations of 58 were determined as $2 R, 4 R, 5 S, 10 S, 13 R, 16 S$ using ECD spectra and TD-DFT comparison method at the B3LYP/6-31G(d) level. By analogy, the absolute configurations of 59-61 were also determined by calculating the ECD [51].

Recently, Liu et al. [10] reported pericoannosin G (62) to be the product of the oxidative cleavage of pericoannosins $C(58)$ and $E(60)$ in its biosynthetic pathway. The structure was determined using ${ }^{1} \mathrm{H}-\mathrm{NMR},{ }^{13} \mathrm{C}-\mathrm{NMR}$, DEPT, HSQC, HMBC, ${ }^{1} \mathrm{H}-{ }^{1} \mathrm{H}$ COSY, and NOESY spectroscopic data. The absolute configuration of $\mathbf{6 2}$ was determined as $2 R, 3 S, 8 S, 11 R$ and was calculated using the TD-DFT method at the B3LYP/6-31G(d) level (10).

Several polyketide pathway compounds were obtained from the Periconia genus. There are chlorinated coumarin derivates of 5-chloro-3.4-dihydro-8-hydroxy-6-methoxy-3methylisocoumarin (63) obtained from P. macrospinosa with medium Czapeck-Dox by NMR varian A60, and HA100 [53]. Henderson et al., [54] isolated 3,4-dihydro-6,8-hydroxy-6methoxy-3-methylisocoumarin (64) and 3,4-dihydro-8-hydroxy-6-methoxy-3-methylisocoumarin (65) when clorine are depleted from the medium.

Some polyketide-peptide hybrid compounds pathways were obtained from P. circinata (Mangin) Sacc with the part origin and crown root of the grain sorghum, Sorghum bicolor (L.). The first compound was circinatin (66), which has a biogenetic relationship with PCtoxins. It is the important pathogenicity factor from endophytic fungi P. circinata causing disease symptoms on its host plant, which is the cultivars of sorghum [55]. After two years, Macko et al., isolated the suspected toxins such as peritoxin A-B (67-68), along with periconin A-B (69-70) [56]. From the structural comparison studied, circinatin (66) was reported to be the precursor for the formation of peritoxin A-B (67-68) [56].

Furthermore, macrosphelides, macrolide, and cyclopentenone compounds were also isolated from the Periconia genus. These compounds were synthesized through the polyketide pathway [57-59]. Modiolide A (71) is a macrolide compound isolated from P. siamensis and obtained from the leaves of T. lafifolia $[60,61]$. The relative structures were determined by IR, NMR, and Mass Spectra [60]. Meanwhile, crystal structures were examined by Fun et al., [61], and the absolute configurations at $C 4, C 7$, and $C 9$ were assigned and determined by the exciton chirality method using the $p$-methoxycinnamoyl chloride treatment. For the first time, $\mathbf{7 1}$ was obtained as a colorless oil from fungus Paraphaeosphaeria sp. (strain $\mathrm{N}-119$ ) derived from a marine horse mussel Modiolus auriculatus [62].

Macrosphelides is another macrolide member isolated from $P$. byssoides symbionts of sea hare A. kurodai and during the chemical investigation, a total of ten were isolated. Numataetal. [6] reported the macrosphelides E, F- $\mathrm{H}(\mathbf{7 4}, \mathbf{7 6}-\mathbf{7 8})$ along with $\mathrm{C}$ (73), and their structures were established based on ${ }^{1} \mathrm{H}-\mathrm{NMR},{ }^{13} \mathrm{C}-\mathrm{NMR}, \mathrm{DEPT},{ }^{1} \mathrm{H}-{ }^{1} \mathrm{H}$ COSY, ${ }^{1} \mathrm{H}-{ }^{13} \mathrm{C}$ COSY, and HMBC spectral analysis. Furthermore, these compounds were re-isolated along with macrosphelide A (72) and I (79) by Yamada et al. [63]. In this report, the determination of the absolute stereochemistry of $\mathbf{7 4}, \mathbf{7 6}, \mathbf{7 7}$, and $\mathbf{7 9}$ were conducted using $1 \mathrm{D}$ and 2D NMR spectral analysis and some chemical transformations. Furthermore, the absolute configuration of macrosphelide C (73) was determined using X-ray analysis and application of the modified Mosher method [63]. The next macrosphelide is seco-macrosphelide $\mathrm{E}$ (75), which has a similar configuration as macrosphelide E, followed by $\mathrm{H}$ (78) and L (79) along with their absolute stereochemistry based on spectroscopic analysis $[64,65]$. The recent investigation of macrosphelide compounds from Periconia was conducted in 2007, where macrosphelide $\mathrm{M}$ (81) was isolated along with the determination of its absolute stereochemistry. This was conducted using 1D and 2D NMR techniques and some chemical transformations including the modified Mosher's method [33]. 
Moreover, cyclopentenones were also isolated from P. macrospinosa by Giles and Turner [53]. There are 2-allyl-3,5-dichloro-1,4-dihydroxycyclopent-2-enoate methyl ester (82), Cryptosporiopsinol (84), and Cryptosporiopsin (85) isolate. Their fermentation was conducted using a Czapeck-Dox medium, and their structures were determined by NMR Varian A60 and HA100. Inose et al. [57] isolated another cyclopentenone, from P. macrospinosa cyclopericodiol (83), and the biosynthetic relation between melleins and the keto-form derivative was also proposed to yield 83. A summary of the number and types of polyketides obtained from the genus Periconia is demonstrated in Table 1, while Figures 4 and 5 showed the structure of the polyketide compounds.

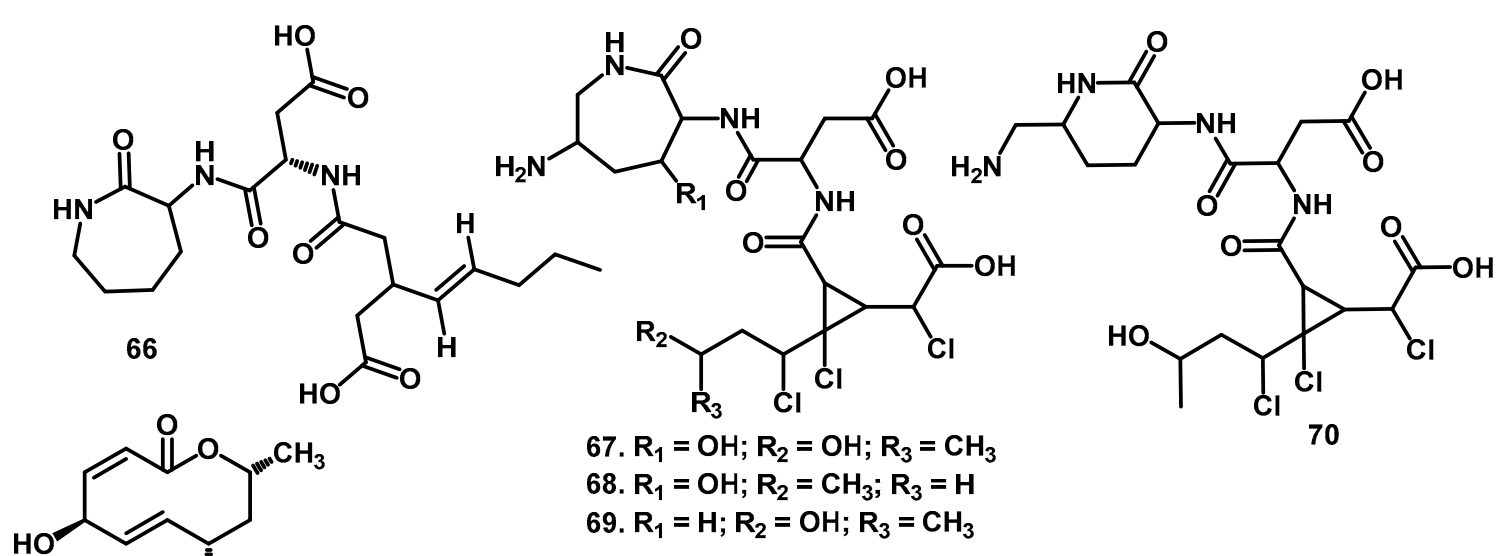

71<smiles>[R]C(/C=C/C(=O)OC(C)CC(=O)O[C@H](C)[C@@H](C)O)[C@@H](C)OC(=O)/C=C\C(=O)O</smiles><smiles>[R]C(/C=C/C(=O)O[C@@H](C)CC(=O)O[C@H](C)C([R2])CCC(=O)O)[C@@H](C)OC(=O)C[C@H]([R])C</smiles>

74. $R_{1}=R_{2}=O H$

76. $\mathrm{R}_{\mathbf{1}}=\mathrm{H} ; \mathrm{R}_{\mathbf{2}}=\mathrm{OH}$

77. $\mathrm{R}_{1}=\mathrm{OH} ; \mathrm{R}_{2}=\mathrm{H}$

72. $\mathrm{R}=\mathrm{OH}$

73. $\mathbf{R}=\mathrm{H}$<smiles>CC(=O)C[C@H](CC(=O)O[C@H](C)C/C=C\C(=O)O[C@H](C)[C@@H](O)/C=C/C(=O)O)OC(C)=O</smiles><smiles>C[C@H](O)C(=O)/C=C\C(=O)O[C@H](C)[C@@H](C)OC(=O)/C=C/C(=O)O[C@@H](C)C(=O)O</smiles>

80<smiles>CC(=O)C[C@@H](C)OC(=O)/C=C/[C@@H](O)[C@H](O)[C@@H](O)OC(=O)/C=C/[C@@H](O)C(C)O</smiles>

75

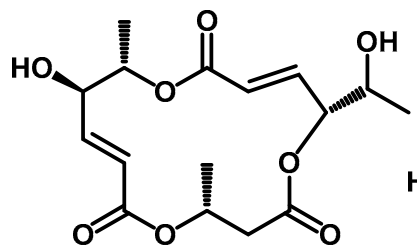

81

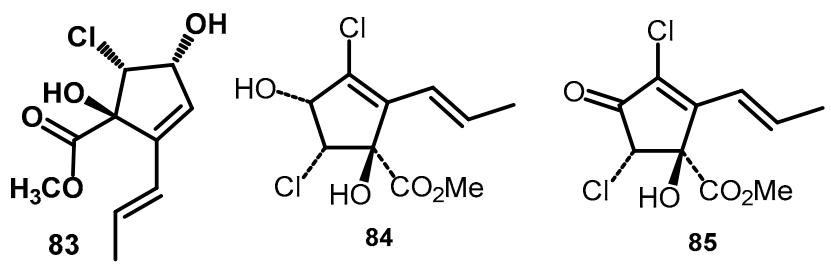

Figure 5. The chemical structures of polyketides 66-85 from the Periconia genus.

\subsection{Aromatic Compounds and Carbohydrates Derivates}

Fourteen aromatic compounds were isolated from this genus. These include 6,8dimethoxy-3-(20-oxo-propyl)-coumarin (86) and 2,4-dihydroxy-6-[(10E,30E) -penta-1',3'dienyl]-benzaldehyde (87), which were isolated from $P$. atropurpurea in the leaves of Xylopia aromatica [11]. Others are 4-chromanone, 6-hydroxy-2-methyl-(5CI) (88), isolated from $P$. 
siamensis in the leaves of T. latifolia [60]. Subsequently, many aromatic compounds derived from the polyketone biosynthetic pathway were isolated from Periconia sp., Parmelia sp., pericocins A-D (89-92), 3-(2-oxo-2H-pyran-6-yl)propanoic acid (93), and (E)-3-(2-oxo2H-pyran-6-yl)acrylic acid (94) [9]. The other aromatic compounds were obtained from three melleins (3R,4S)-5-chloro-4-hydroxy-6-methoxymellein (95), ( $R$ )-7-chloro-6-methoxy8-O-methyl-mellein (96), and (R)-5-chloro-6-methoxy-mellein (97) from P. macrospinosa KT3863 [57]. In addition, the same endophytic fungi Periconia sp., which was isolated from the different host plant, $A$. muricat $a$ was the source of chlorine-containing dihydroisocoumarin perichlorosins A (98) and a chlorinated phenol pericochlorosin B (99) [10]. The structures of all the aromatic compounds were determined by extensive 1D and 2D NMR for relative configurations.

The carbohydrate carbasugar derivates pericosine A (100) and B (101) were isolated from $P$. byssoides in the sea hare A. kurodai through reverse-phase HPLC [6]. In addition, these compounds were re-isolated in 2007 from the same natural source along with pericosine C-E (102-104), which was separated as enantiomeric mixtures [66]. Spectroscopic analyses including NMR, MS, and IR led to the elucidation of their structures. Additionally, the structure of pericosine $\mathrm{D}(\mathbf{1 0 3})$ was revised by (-)-quinic acid precursor synthesis to methyl (3R,4R,5S,6R)-6-chloro-3,4,5-trihydroxy-1-cyclohexene-1-carboxylate [67]. Table 1 shows the summary of the number and types of aromatic compounds as well as carbohydrate derivates obtained from the genus Periconia, while Figure 6 shows the structure of compounds.<smiles>CC(=O)/C=C/C=C/c1cc(O)cc(O)c1C(C)=O</smiles><smiles>COc1cc2oc(C)c(C)c(=O)c2c(O)c1O</smiles><smiles>[R]C(CC(=O)O)c1cccc(=O)o1</smiles><smiles>O=C(O)/C=C/c1cccc(=O)o1</smiles>

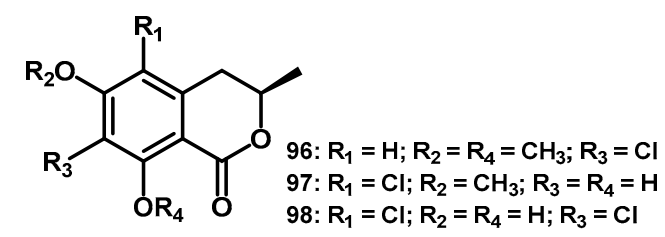<smiles>COc1c(O)c(CC(C)O)c(Cl)c(O)c1Cl</smiles>

99<smiles>COC(=O)C1=C[C@@H](O)[C@H](O)[C@H](O)[C@H]1OC</smiles>

101<smiles>COC(=O)C1=C[C@@H](O)[C@H](O)[C@H](O)[C@H]1OC</smiles>

102<smiles>COC(=O)C1=C[C@@H](O)[C@H](O)[C@H](O)[C@H]1Cl</smiles>

103<smiles>COC(=O)C1=C[C@@H](O)[C@H](O)[C@H](O)[C@H]1O[C@@H]1[C@H](Cl)C(OC(C)=O)=C[C@@H](O)[C@@H]1O</smiles>

104

Figure 6. The chemical structures of aromatic compounds 86-99 and carbohydrate derivates 100-104 from the Periconia genus.

\section{Pharmacological Activities}

Some metabolites of the genus Periconia have shown pharmacological activities for a long time. This genus has tremendous activities such as acting as antimicrobial (antibacterial, antifungal and anti-HIV), potent cytotoxicity, and anti-inflammatory agents [6-9,11-13,43,53,62]. 


\subsection{Antimicrobial Activity}

The compounds from the Periconia genus have shown antimicrobial activities for numerous bacterial, fungi, and also human immunodeficiency virus. Bhilabutra et al. [60] accessed antibacterial properties from P. siamensis CMUGE015 associated with T. latifolia in modiolide A (71) and 4-chromanone as well as 6-hydroxy-2-methyl-(5CI) (88). The metabolites $\mathbf{7 1}$ inhibit more Gram-positive bacteria rather than Gram-negative. The results showed that the third compound could inhibit Bacillus cereus, Listeria monocytogenes, Methicillinresistant Staphylococcus aureus (MRSA), Pseudomonas aeroginosa, and Escherichia coli with Minimum Inhibitory Concentration (MIC) value of 3.12, 6.25, 25, 12.5 and $50 \mu \mathrm{g} / \mathrm{mL}$, respectively. As a comparison, penicillin $\mathrm{G}$ can be used for standard control with MIC values $6.25,6,25,25,12,5$, and $50 \mu \mathrm{g} / \mathrm{mL}$, respectively. These bacteria are common human pathogen agents, which can cause foodborne disease, listeriosis, skin infection, and lung disease [60]. Furthermore, the second compound from this fungi, $\mathbf{8 8}$ has antibacterial activity with MIC values of $6.25,12.5,50,12.5$ and $100 \mu \mathrm{g} / \mathrm{mL}$, respectively [62]. The similar structure of this lactone compound, tuckolide, synthesized by Andrus and Shih, acts as an inhibitor for cholesterol in liver cells [68].

An ergosterol, periconiastone A (38) isolated from Periconia sp. TJ403-rc01 also exhibits significant antibacterial activity against $S$. aureus with MIC $4 \mu \mathrm{g} / \mathrm{mL}$ and E. faecalis with MIC $32 \mu \mathrm{g} / \mathrm{mL}$ [42]. Furthermore, fussiococanne diterpenes, periconicin A (9), and B (10) have antibacterial effects on Escherichia coli (ATCC 25922), Bacillus subtilis (ATCC 6633), Staphylococcus aureus (ATCC 6538p), Staphylococcus epidermis (ATCC 12228), Salmonella typhimurium (ATCC 14028) Micrococcus leuteus (IFO 12708), Proteus vulgaris (ATCC 3851). Klebisella pneumoniae (IFO 13541) has several MIC values. For comparison, gentamicin used with a MIC value $1.56,3.12,3.12,3.12,3.12,6.12,6.12,12.5 \mu \mathrm{g} / \mathrm{mL}$, respectively. Periconicin A (9) exhibited significant antibacterial activity with MIC range of $3.12-12.5 \mu \mathrm{g} / \mathrm{mL}$ and B (10) in the range of $25-50 \mu \mathrm{g} / \mathrm{mL}$ [25]. Additionally, periconicin A (7), also tested for antifungal activity, and has potent activity against human mycoses Candida albicans, Trichophyton mentagrophytes, T. rubrum with MIC in the range of $6.25,6.25,3.12 \mu \mathrm{g} / \mathrm{mL}$ with a control antifungal nystatin MIC range of 3.12, 1.56, $0.78 \mu \mathrm{g} / \mathrm{mL}$, respectively [69].

Meanwhile, Teles et al. [11] isolated periconicin B (10) from P. atropurpurea and tested for anti fungi against Cladosporium sphaerospermum and C. cladosporioides through the direct bioautography method with $25.0 \mu \mathrm{g}$ limit detection (weak activity). From the same species, 2,4-dihydroxy-6-[(10E,30E)- penta-10,30-dienyl]-benzaldehyde (87) has vigorous activity against both fungal with $1 \mu \mathrm{g}$ limit detection compared to nystatin as a positive control (no information about limit detection).

Pericocins A-D (89-92) were obtained from endolichenic fungi, Periconia sp. that has a moderate and weak activity to Aspergillus niger (MIC value of $31 \mu \mathrm{g} / \mathrm{mL}$ ) and C. albicans (MIC value of $500 \mu \mathrm{g} / \mathrm{mL}$ ) [9] respectively. Additionally, pericoterpenoid A (24) showed moderate and weak activity to $A$. niger with MIC $31 \mu \mathrm{g} / \mathrm{mL}$, and C. albicans with MIC $500 \mu \mathrm{g} / \mathrm{mL}[8]$.

HIV is a virus that attacks the human immune system, and if it is not treated, can lead to AIDS (Acquired Immunodeficiency Syndrome). Liu et al. [10] accessed the isolated compound Pericochlorosin B (99) for anti-HIV activity. The $\mathrm{IC}_{50}$ value of 99 is $2.2 \mu \mathrm{M}$ compared to positive control efavirenz with an $\mathrm{IC}_{50}$ value of $1.4 \mathrm{nM}$ by Firefly Luciferase Assay System. The other compounds, pericochlorosin A (98) and pericoannosin G (62), were also tested for the same assay, but they have weak activity with an $\mathrm{IC}_{50}$ value of $>100 \mu \mathrm{M}$ [10]. A meroterpene, periconone B (42) has weak anti-HIV activity with an $\mathrm{IC}_{50}$ value of $18 \mathrm{mM}$ [43]. Additionally, cytochalasans from Periconia, periconiasin F (51) [49], G (52) and J (55) [51] have weak activity with an $\mathrm{IC}_{50}$ value of 29.2, 67.0, $25.0 \mu \mathrm{M}$, respectively. Other polyketides, Pericoannosin B (57) [52], C (58), D (59) and F (61), also have weak activity with $\mathrm{IC}_{50}$ with a value $>100,15.5,13.5$ and $81.5 \mu \mathrm{M}$, respectively. From this genus, periconicin A (9) has antimicrobial potential, and pericochlorosin B (99) can be used as an anti-HIV agent in future developments. 


\subsection{Cytotoxic Activity}

The cytotoxic effects of compounds isolated compounds from the genus of Periconia have shown promising activities against some of the cancer cells. Carbasugars, pericosine A (100), and B (101), were significant growth inhibitors of murine P-388 leukemia cell line with $\mathrm{ED}_{50} 0.1$ and $4.0 \mu \mathrm{g} / \mathrm{mL}$ [6]. Pericosine A (100) also exhibited significant in vivo tumor-inhibitory activity against P-388 in mice and inhibited protein kinase EGFR (at a concentration of $100 \mu \mathrm{g} / \mathrm{mL}$ by $40-70 \%$ ) and topoisomerase II (with $\mathrm{IC}_{50}$ value of 100-300 mM) [66]. These two compounds were studied in synthetic ways for lead cancer drugs [70-84].

Eremophilane-type sesquiterpenoid, peribysins A-D (11-14) from P. byssoides symbion of sea hare A. kurodai, showed promising inhibition of the adhesion of Human Leukimia HL-60 cells line and Human Umbilical Vein Endothelial Cell (HUVEC) with IC 50 values of $0.3,2.7,2.7$, and $0.1 \mu \mathrm{M}$, respectively [13]. Compounds from this same species and host peribysins E-G (15-17) [31] as well as H-J (16-18) [32] were tested. They were successfully inhibited by similar cell lines with $\mathrm{IC}_{50}$ values of $11.5,20.7,15.6,15.2,20.1$, and $11.8 \mu \mathrm{M}$ compared with herbimycin A with $\mathrm{IC}_{50}$ value of $38 \mu \mathrm{M}$. Peribysins D (14) showed promising inhibition activity of HL-60 cells to HUVEC, more potent 380 times than herbimycin A [13].

Macrosphelide, a potent inhibitor of adhesion HL-60 cells to HUVEC was initially isolated from Microsphaeropsis sp. FO-5050 [85]. These compounds have also been produced by $P$. byssoides symbion of sea hare A. kurodai. Macrosphelides A (72), C (73), E (74), F (76), G (77), H (78) [63], and L (80) [65] were also isolated from this species. They have anti-adherent activity against HL-60 and HUVEC with $\mathrm{IC}_{50}$ values of 18.7, 36.5, 19.5, 27.2, $22.5,8.6$, and $5.6 \mu \mathrm{M}$ with the positive control, herbimycin A $38 \mu \mathrm{M}$. Numata et al., [6] tested macrosphelides E (74), F (76), G (77) and H (78) to P388 lymphocytic leukemia cell culture with cytotoxicity $\mathrm{ED}_{50}>100 \mu \mathrm{g} / \mathrm{mL}$.

The HST -8 (Human Ileocecal Adenocarcinoma) and BGC-823 (Human Gastric Cancer) cell lines were successfully inhibited by periconiasin A (46) and B (47) cytochalasans from Periconia sp. F-31. Both cell lines were inhibited by periconiasin A (46) with $\mathrm{IC}_{50}$ values of 0.9 and $2.1 \mu \mathrm{M}$ and periconiasin $\mathrm{B}(47)$, with $\mathrm{IC}_{50}$ values of 0.8 , and $9.4 \mu \mathrm{M}$, respectively. Furthermore, periconiasin B (47) also tested for Bel-7402, a human hepatoma cell line with $\mathrm{IC}_{50}$ values $5.1 \mu \mathrm{M}$ [49]. Another cytochalasan, periconiasin I (54) and meroterpenes periconone $\mathrm{E}$ (45), showed in vitro cytotoxicity against human MCF-7 tumour cell line with an $\mathrm{IC}_{50}$ value of 4.8 and $4.2 \mu \mathrm{M}$ [50].

Periconicin B (10), a fusicoccane-type diterpenoid is isolated from Periconia sp. small branches of T. cuspidata [25] and P. atropurpurea from leaves Xylopia aromatica [11]. It has decreased levels of HeLa and $\mathrm{CHO}$ cell viability, with an $\mathrm{IC}_{50}$ value of $8.0 \mu \mathrm{M}$, and the constituent showed similar potency known as antiplastic agent Cisplatin ( $\mathrm{IC}_{50}$ value of $5.0 \mu \mathrm{M})$ [11]. Meanwhile, other terpenoids (+)-(3S,6S,7R,8S)-periconone A (36) and (-)$(1 R, 4 R, 6 S, 7 S)-2$-caren-4,8-olide (8) have weak cytotoxic activities against six human tumor cell lines (HCT-8, Bel-7402, BGC-823, A549, A2780 and MCF-7) with $\mathrm{IC}_{50}>10^{-5} \mathrm{mM}$ [23].

Therefore, Pericosine A (100) is the best growth inhibitor for the P-388 leukemia cell line with $\mathrm{ED}_{50} 0.1 \mu \mathrm{g} / \mathrm{mL}$, peribysin D (14) for HL-60 cells and HUVEC inhibitors with $\mathrm{IC}_{50} 0.1 \mu \mathrm{M}$. Periconiasin B (46) is good for HST -8 and BGC-823 inhibitors with $\mathrm{IC}_{50}$ values of $0.8 \mu \mathrm{M}$, Periconone E (45) is good for the MCF-7 tumor cell line with $\mathrm{IC}_{50} 4.2 \mu \mathrm{M}$, and Periconicin B (10) is good for HeLa and CHO cells with $\mathrm{IC}_{50} 8.0 \mu \mathrm{M}$. These previously mentioned compounds may be potential for future cancer treatments.

\subsection{Anti-Inflammatory Activity}

Sesquiterpenoid, periconianone A (25), B (26), and norsesquiterpenoid dihydronaphthalene-2,6-dione (37) from Periconia sp. and host $A$. muricata were tested using lipopolysaccharide (LPS)-induced NO production in mouse microglia BV2 G13 cells for neural antiinflammatory activity. These compounds exhibited significant inhibition with $\mathrm{IC}_{50}$ values of $0.15,0.38$, and $0.23 \mu \mathrm{M}$ compared with curcumin as a positive control with $\mathrm{IC}_{50}$ 
$3.9 \mu \mathrm{M}$ [38]. Similarly, periconianone D (28), G (31) and K (35) also have inhibition effects on lipopolysaccharide-induced NO production in BV2 cells $10.2 \%, 18.3 \%$, and $16.1 \%$, respectively, compared with curcumin $12.9 \%$ inhibition at dose $1.0 \mu \mathrm{M}$ [39]. Furthermore, microglia are essential immune cells in the central nervous system, that play a critical role in Parkinson's and Alzheimer's Disease [86,87]. Therefore, periconianone A (25), B (26), and dihydronaphthalene-2,6-dione (37), may be potential as a lead compound for Parkinson's and Alzheimer's Disease drug candidates [38].

\section{Conclusions and Future Perspectives}

In summary, after being researched for almost 50 years, Periconia fungal genus was found to live in a different ecological niche such as plants, lichens, and animals. Moreover, this fungus can produce plenty of secondary metabolites with various natural products such as terpenes, polyketides, aromatic compounds, and carbohydrate derivates. Owing to these exciting finds, eventually, the fungus has excellent potential to be a rich source for natural product exploration and can be studied for pharmacological agents.

In this review, several Periconia species were studied for natural product exploration, such as Periconia sp., Periconia atropurpurea, Periconia byssoides, Periconia macrospinosa, Periconia circinata, and Periconia siamensis. All these species were found from eight plants (Annona muricata, Taxus cuspidata, Xylopia aromatica, Thysanoleana latifolia, Sorghum bicolor, Rosa chinensis, Piper longum, and terrestrial herbaceous plants). Additionally, there was one lichen (Parmelia sp.) and one sea animal (Aplysia kurodai). From all Periconia species that were already isolated, there are 104 total compounds that were studied from July 1969 to October 2020.

All these compounds have a diverse pharmacological activity that makes research of this genus more interesting. One exciting fact is that Periconia was studied for taxol and piperine production. This fungus can produce these host compounds (high-level plants) and if it lives as endophytes. In addition, it turns out that this Periconia fungus can produce new secondary metabolites that differ from the characteristics of the metabolites of the host plant. This tremendous discovery makes fungus a gold mine for natural product exploration, and it is fascinating to study their pharmacological activity.

Several potential compounds from the Periconia which have pharmacological activity are periconicin A (9), which acts as an antimicrobial, pericochlorosin B (99) possesses anti-HIV properties, peribysin D (14), and pericosine A (100), has vigorous cytotoxic activity, periconianone A (23) can be used as an anti-inflammatory. However, further studies are needed for the action mechanism of apoptosis study. For example, the cytotoxic mechanism of the carbasugar derivate (100). There are intrinsic mechanism studies of mitochondria-dependent cytochrome $C$, caspase activation, and extrinsic mechanisms of apoptosis (activation of tumor necrotic factor). The mechanism of how this compound can induce apoptosis may lead to new perspectives. On the other hand, the study of the mechanism of anti-inflammatory sesquiterpenoid compounds $(\mathbf{2 5}, \mathbf{2 6}, \mathbf{3 7})$ in BV2 G13 microglia cells needs to be continued for further testing, such as the production of nitrite, iNOS (inducible nitric oxide synthase) mRNA, and protein expression.

Further intensive investigations are recommended concerning how the Periconia fungus may produce other new compounds by genetic manipulation. There are mutasynthesis, heterologous expression, and metabolic engineering at genomic level, transcriptome, and proteome (enzyme inhibition, direct precursor biosynthesis, substrate feeding) level treatments. Furthermore, the modification of fungal media can also be carried out using the principle of OSMAC (one strain many compounds), epigenetic modification, semi-synthetic media, and even by Co-Culture with other microorganisms. This treatment may induce the silent gene of the Periconia fungus to produce another interesting new compound. Furthermore, omics level studies (metabolomics) using LC-MS or GC-MS tools can identify the new compounds and compare all the treatments. Lastly, the discoveries of new compounds from fungi such as Periconia are always interesting for pharmacological studies and future lead compounds. 
Table 1. Compounds from the Periconia fungal genus: type of compounds, MW and MS data, strain type, various host and origins.

\begin{tabular}{|c|c|c|c|c|c|c|c|c|}
\hline $\begin{array}{c}\text { Type of } \\
\text { Compounds }\end{array}$ & Name of Compounds & $\begin{array}{l}\text { Molecular } \\
\text { Formula }\end{array}$ & $\begin{array}{c}\text { Molecular } \\
\text { Weights (g/mol) }\end{array}$ & MS $(m / z)$ & Fungal Strains & Host Origin & Part of Host Origin & Ref. \\
\hline & & & & Terpenes & & & & \\
\hline \multirow{6}{*}{ Monoterpene } & 2-carene-5,8-diol (3) & $\mathrm{C}_{10} \mathrm{H}_{16} \mathrm{O}_{2}$ & 168.1150 & $\begin{array}{c}\text { HR-ESI-MS: } 151.1115 \\
{\left[\mathrm{M}+\mathrm{H}_{-}-\mathrm{H}_{2} \mathrm{O}\right]^{+}, 133.1011[\mathrm{M}} \\
\left.+\mathrm{H}-2 \mathrm{xH}_{2} \mathrm{O}\right]^{+} ; \mathrm{GC}-\mathrm{EI}-\mathrm{MS}: 168 \\
{[\mathrm{M}]^{+}, 150\left[\mathrm{M}-\mathrm{H}_{2} \mathrm{O}\right]^{+}} \\
\text {HR-ESI-MS: } 151.1112\end{array}$ & Periconia sp. F-31 & Annona muricata & Leaves & [19] \\
\hline & 2-carene-8,10-diol (4) & $\mathrm{C}_{10} \mathrm{H}_{16} \mathrm{O}_{2}$ & 168.1150 & $\begin{array}{c}{\left[\mathrm{M}+\mathrm{H}_{-} \mathrm{H}_{2} \mathrm{O}\right]^{+}, 133.1008[\mathrm{M}} \\
\left.+\mathrm{H}-2 \mathrm{xH}_{2} \mathrm{O}\right]^{+} ; \text {GC-EI-MS: } 168 \\
{[\mathrm{M}]^{+}, 150\left[\mathrm{M}-\mathrm{H}_{2} \mathrm{O}\right]^{+}}\end{array}$ & Periconia sp. F-31 & Annona muricata & Leaves & [19] \\
\hline & 2-carene-8-acetamide (5) & $\mathrm{C}_{12} \mathrm{H}_{19} \mathrm{NO}$ & 193.1467 & $\begin{array}{c}\text { HR-ESI-MS: } 194.1509[\mathrm{M}+\mathrm{H}]^{+} \\
387.2942[2 \mathrm{M}+\mathrm{H}]^{+}\end{array}$ & Periconia sp. F-31 & Annona muricata & Leaves & [19] \\
\hline & $\begin{array}{l}\text { 8-hydroxy-1,7-expoxy-2- } \\
\text { menthene (6) }\end{array}$ & $\mathrm{C}_{10} \mathrm{H}_{16} \mathrm{O}_{2}$ & 168.1150 & $\begin{array}{c}\text { HR-ESI-MS: } 151.1112 \\
{\left[\mathrm{M}+\mathrm{H}-\mathrm{H}_{2} \mathrm{O}\right]^{+} ; \mathrm{GC}-\mathrm{EI}-\mathrm{MS}: 168} \\
{[\mathrm{M}]^{+}, 153\left[\mathrm{M}-\mathrm{CH}_{3}\right]^{+}}\end{array}$ & Periconia sp. F-31 & Annona muricata & Leaves & [19] \\
\hline & \multirow{2}{*}{$\begin{array}{c}\text { anethofuran }(7) \\
(-)-(1 R, 4 R, 6 S, 7 S)-2 \text {-caren- } \\
4,8 \text {-olide }(8)\end{array}$} & $\mathrm{C}_{10} \mathrm{H}_{16} \mathrm{O}_{2}$ & 168.1150 & ${ }^{*}$ HR-ESI-MS: $169.1229[\mathrm{M}+\mathrm{H}]^{+}$ & Periconia sp. F-31 & Annona muricata & Leaves & [19] \\
\hline & & $\mathrm{C}_{10} \mathrm{H}_{12} \mathrm{O}_{2}$ & 164.0837 & HR-ESI-MS: 165.0914 [M+H] ${ }^{+}$ & Periconia sp. F-31 & Annona muricata & Leaves & [23] \\
\hline \multirow{2}{*}{ Diterpene } & periconicin A (9) & $\mathrm{C}_{20} \mathrm{H}_{28} \mathrm{O}_{3}$ & 316.2038 & HR-EI-MS: $316.2046[\mathrm{M}+\mathrm{H}]^{+}$ & Periconia sp. & Taxus cuspidata & Small Branches & [25] \\
\hline & periconicin B (10) & $\mathrm{C} 20 \mathrm{H} 28 \mathrm{O} 4$ & 332.1988 & HR-EI-MS: 332.2008 [M+H]+ & Periconia atropurpurea & Xylopia aromatica & Leaves & [11] \\
\hline \multirow{12}{*}{ Sesquiterpene } & peribysin B (12) & $\mathrm{C}_{15} \mathrm{H}_{24} \mathrm{O}_{4}$ & 268.1673 & HR-EI-MS: 268.1665 [M] $^{+}$ & Periconia byssoides & Aplysia kurodai & gastrointestinal tract & {$[13,34$} \\
\hline & peribysin C (13) & $\mathrm{C}_{15} \mathrm{H}_{22} \mathrm{O}_{2}$ & 234.1619 & HR-EI-MS: 234.1619 [M] $^{+}$ & Periconia byssoides & Aplysia kurodai & gastrointestinal tract & {$[13,34$} \\
\hline & peribysin D (14) & $\mathrm{C}_{15} \mathrm{H}_{22} \mathrm{O}_{2}$ & 234.1619 & HR-EI-MS: 234.1618 [M] $^{+}$ & Periconia byssoides & Aplysia kurodai & gastrointestinal tract & [13] \\
\hline & peribysin E (15) & $\mathrm{C}_{20} \mathrm{H}_{30} \mathrm{O}_{6}$ & 366.2042 & HR-EI-MS: $366.0948[\mathrm{M}]^{+}$ & Periconia byssoides & Aplysia kurodai & gastrointestinal tract & [31] \\
\hline & peribysin F (16) & $\mathrm{C}_{21} \mathrm{H}_{32} \mathrm{O}_{7}$ & 396.2148 & HR-EI-MS: $396.1677[\mathrm{M}]^{+}$ & Periconia byssoides & Aplysia kurodai & gastrointestinal tract & {$[13,34]$} \\
\hline & peribysin G (17) & $\mathrm{C}_{21} \mathrm{H}_{32} \mathrm{O}_{7}$ & 396.2148 & HR-EI-MS: 396.1677 [M] $^{+}$ & Periconia byssoides & Aplysia kurodai & gastrointestinal tract & {$[13,34]$} \\
\hline & peribysin H (18) & $\mathrm{C}_{15} \mathrm{H}_{24} \mathrm{O}_{4}$ & 268.1673 & HR-EI-MS: 268.1673 [M] ${ }^{+}$ & Periconia byssoides & Aplysia kurodai & gastrointestinal tract & [32] \\
\hline & peribysin I (19) & $\mathrm{C}_{15} \mathrm{H}_{24} \mathrm{O}_{4}$ & 268.1673 & HR-EI-MS: 268.1673 [M]+ & Periconia byssoides & Aplysia kurodai & gastrointestinal tract & [32] \\
\hline & peribysin J (20) & $\mathrm{C}_{15} \mathrm{H}_{26} \mathrm{O}_{5}$ & 286.1773 & HR-EI-MS: 268.1775 [M] $^{+}$ & Periconia byssoides & Aplysia kurodai & gastrointestinal tract & [33] \\
\hline & peribysin $\mathrm{O}(21)$ & $\mathrm{C}_{15} \mathrm{H}_{22} \mathrm{O}_{4}$ & 266.1518 & $\begin{array}{c}\text { ESI-TOF-MS: } 289.1416[\mathrm{M}+\mathrm{Na}]^{+} ; \\
555.2919[2 \mathrm{M}+\mathrm{Na}]^{+}\end{array}$ & $\begin{array}{l}\text { P. macrospinosa } \\
\text { KT3863 }\end{array}$ & $\begin{array}{l}\text { terrestrial herbaceous } \\
\text { plant at Kanagawa } \\
\text { prefecture in } 2018\end{array}$ & - & [37] \\
\hline & peribysin $\mathrm{P}(22)$ & $\mathrm{C}_{15} \mathrm{H}_{24} \mathrm{O}_{4}$ & 268.1675 & $\begin{array}{c}\text { ESI-TOF-MS: } 291.1566[\mathrm{M}+\mathrm{Na}]^{+} ; \\
559.3230[2 \mathrm{M}+\mathrm{Na}]^{+}\end{array}$ & $\begin{array}{l}\text { P. macrospinosa } \\
\text { KT3863 }\end{array}$ & $\begin{array}{l}\text { terrestrial herbaceous } \\
\text { plant at Kanagawa } \\
\text { prefecture in } 2018\end{array}$ & - & [37] \\
\hline & peribysin Q (23) & $\mathrm{C}_{15} \mathrm{H}_{20} \mathrm{O}_{3}$ & 248.1412 & $\begin{array}{c}\text { ESI-TOF-MS: } 249.1496[\mathrm{M}+\mathrm{H}]^{+} ; \\
231.1388\left[\mathrm{M}+\mathrm{H}-\mathrm{H}_{2} \mathrm{O}^{+} ; 271.1311\right. \\
{[\mathrm{M}+\mathrm{Na}]^{+}}\end{array}$ & $\begin{array}{l}\text { P. macrospinosa } \\
\text { KT3863 }\end{array}$ & $\begin{array}{l}\text { terrestrial herbaceous } \\
\text { plant at Kanagawa- } \\
\text {-prefecture in } 2018\end{array}$ & - & [37] \\
\hline
\end{tabular}


Table 1. Cont.

\begin{tabular}{|c|c|c|c|c|c|c|c|c|}
\hline $\begin{array}{c}\text { Type of } \\
\text { Compounds }\end{array}$ & Name of Compounds & $\begin{array}{l}\text { Molecular } \\
\text { Formula }\end{array}$ & $\begin{array}{c}\text { Molecular } \\
\text { Weights (g/mol) }\end{array}$ & MS $(m / z)$ & Fungal Strains & Host Origin & Part of Host Origin & Ref. \\
\hline & pericoterpenoid A (24) & $\mathrm{C}_{15} \mathrm{H}_{16} \mathrm{O}_{3}$ & 244.1099 & HR-ESI-MS: $267.1002[\mathrm{M}+\mathrm{Na}]^{+}$ & Periconia sp. & Parmelia sp. & - & {$[8]$} \\
\hline & periconianone A (25) & $\mathrm{C}_{15} \mathrm{H}_{18} \mathrm{O}_{4}$ & 262.1205 & HR-ESI-MS: $263.1271[\mathrm{M}+\mathrm{H}]^{+}$ & Periconia sp. F-31 & Annona muricata & Leaves & [38] \\
\hline & periconianone B (26) & $\mathrm{C}_{15} \mathrm{H}_{18} \mathrm{O}_{4}$ & 262.1205 & HR-ESI-MS: $263.1280[\mathrm{M}+\mathrm{H}]^{+}$ & Periconia sp. F-31 & Annona muricata & Leaves & [38] \\
\hline & periconianone C (27) & $\mathrm{C}_{15} \mathrm{H}_{20} \mathrm{O}_{4}$ & 264.1362 & HR-ESI-MS: $265.1434[\mathrm{M}+\mathrm{H}]^{+}$ & Periconia sp. F-31 & Annona muricata & Leaves & [39] \\
\hline & periconianone $\mathrm{D}(28)$ & $\mathrm{C}_{15} \mathrm{H}_{20} \mathrm{O}_{3}$ & 248.1412 & HR-ESI-MS: $249.1458[\mathrm{M}+\mathrm{H}]^{+}$ & Periconia sp. F-31 & Annona muricata & Leaves & [39] \\
\hline & periconianone E (29) & $\mathrm{C}_{15} \mathrm{H}_{20} \mathrm{O}_{3}$ & 248.1412 & HR-ESI-MS: $249.1478[\mathrm{M}+\mathrm{H}]^{+}$ & Periconia sp. F-31 & Annona muricata & Leaves & [39] \\
\hline & periconianone F (30) & $\mathrm{C}_{15} \mathrm{H}_{22} \mathrm{O}_{5}$ & 282.1467 & HR-ESI-MS: $283.1540[\mathrm{M}+\mathrm{H}]^{+}$ & Periconia sp. F-31 & Annona muricata & Leaves & [39] \\
\hline & periconianone G (31) & $\mathrm{C}_{15} \mathrm{H}_{24} \mathrm{O}_{4}$ & 268.1675 & HR-ESI-MS: $291.1567[\mathrm{M}+\mathrm{Na}]^{+}$ & Periconia sp. F-31 & Annona muricata & Leaves & [39] \\
\hline & periconianone $\mathrm{H}(32)$ & $\mathrm{C}_{12} \mathrm{H}_{16} \mathrm{O}_{3}$ & 208.1099 & HR-ESI-MS: $209.1172[\mathrm{M}+\mathrm{H}]^{+}$ & Periconia sp. F-31 & Annona muricata & Leaves & [39] \\
\hline & periconianone I (33) & $\mathrm{C}_{12} \mathrm{H}_{16} \mathrm{O}_{3}$ & 208.1099 & HR-ESI-MS: $209.1172[\mathrm{M}+\mathrm{H}]^{+}$ & Periconia sp. F-31 & Annona muricata & Leaves & [39] \\
\hline & periconianone J (34) & $\mathrm{C}_{12} \mathrm{H}_{16} \mathrm{O}_{3}$ & 208.1099 & HR-ESI-MS: $209.1172[\mathrm{M}+\mathrm{H}]^{+}$ & Periconia sp. F-31 & Annona muricata & Leaves & [39] \\
\hline & periconianone K (35) & $\mathrm{C}_{12} \mathrm{H}_{16} \mathrm{O}_{3}$ & 208.1099 & HR-ESI-MS: $209.1172[\mathrm{M}+\mathrm{H}]^{+}$ & Periconia sp. F-31 & Annona muricata & Leaves & [39] \\
\hline & $\begin{array}{c}\text { (+)-(3S,6S,7R,8S)- } \\
\text { periconone A (36) }\end{array}$ & $\mathrm{C}_{15} \mathrm{H}_{22} \mathrm{O}_{5}$ & 282.1467 & HR-ESI-MS: $283.1549[\mathrm{M}+\mathrm{H}]^{+}$ & Periconia sp. F-31 & Annona muricata & Leaves & [23] \\
\hline Norsesqui-terpene & $\begin{array}{l}\text { Dihydronaphthalene-2,6- } \\
\text { dione (37) }\end{array}$ & $\mathrm{C}_{12} \mathrm{H}_{12} \mathrm{O}_{3}$ & 204.0786 & ${ }^{*}$ HR-ESI-MS: $205.0865[\mathrm{M}+\mathrm{H}]^{+}$ & Periconia sp. F-31 & Annona muricata & Leaves & [38] \\
\hline Steroid & periconiastone A (38) & $\mathrm{C}_{28} \mathrm{H}_{42} \mathrm{O}_{3}$ & 426.3134 & HR-ESI-MS: 449.3026 [M+Na] ${ }^{+}$ & $\begin{array}{l}\text { Periconia sp. } \\
\text { TJ403-rc01 }\end{array}$ & Rosa chinensis & Leaves & [43] \\
\hline & pericolactine $C(41)$ & $\mathrm{C}_{23} \mathrm{H}_{35} \mathrm{NO}_{5}$ & 405.2515 & HR-ESI-MS: $428.2418[\mathrm{M}+\mathrm{Na}]^{+}$ & Periconia sp. & Parmelia sp. & - & [7] \\
\hline & periconone B (42) & $\mathrm{C}_{17} \mathrm{H}_{24} \mathrm{O}_{4}$ & 292.1675 & HR-ESI-MS: $293.1741[\mathrm{M}+\mathrm{H}]^{+}$ & Periconia sp. F-31 & Annona muricata & Leaves & [43] \\
\hline & periconone C (43) & $\mathrm{C}_{17} \mathrm{H}_{24} \mathrm{O}_{5}$ & 308.1624 & HR-ESI-MS: $331.1516[\mathrm{M}+\mathrm{Na}]^{+}$ & Periconia sp. F-31 & Annona muricata & Leaves & [43] \\
\hline & periconone D (44) & $\mathrm{C}_{17} \mathrm{H}_{24} \mathrm{O}_{5}$ & 308.1624 & HR-ESI-MS: 331.1516 [M+Na] ${ }^{+}$ & Periconia sp. F-31 & Annona muricata & Leaves & [43] \\
\hline & periconone E (45) & $\mathrm{C}_{15} \mathrm{H}_{22} \mathrm{O}_{5}$ & 282.1467 & HR-ESI-MS: $283.1540[\mathrm{M}+\mathrm{H}]^{+}$ & Periconia sp. F-31 & Annona muricata & Leaves & [43] \\
\hline \multicolumn{9}{|c|}{ Polyketides } \\
\hline \multirow[t]{6}{*}{ Cytochalasan } & periconiasin A (46) & $\mathrm{C}_{22} \mathrm{H}_{33} \mathrm{NO}_{3}$ & 359.2460 & HR-ESI-MS: $360.2528[\mathrm{M}+\mathrm{H}]^{+}$ & Periconia sp. F-31 & Annona muricata & Leaves & [49] \\
\hline & periconiasin B (47) & $\mathrm{C}_{22} \mathrm{H}_{33} \mathrm{NO}_{3}$ & 359.2460 & HR-ESI-MS: $360.2525[\mathrm{M}+\mathrm{H}]^{+}$ & Periconia sp. F-31 & Annona muricata & Leaves & [48] \\
\hline & periconiasin C (48) & $\mathrm{C}_{22} \mathrm{H}_{31} \mathrm{NO}_{3}$ & 357.2304 & HR-ESI-MS: $358.2377[\mathrm{M}+\mathrm{H}]^{+}$ & Periconia sp. F-31 & Annona muricata & Leaves & [48] \\
\hline & periconiasin D (49) & $\mathrm{C}_{22} \mathrm{H}_{33} \mathrm{NO}_{3}$ & 359.2460 & HR-ESI-MS: $360.2533[\mathrm{M}+\mathrm{H}]^{+}$ & Periconia sp. F-31 & Annona muricata & Leaves & [49] \\
\hline & periconiasin E (50) & $\mathrm{C}_{22} \mathrm{H}_{33} \mathrm{NO}_{3}$ & 359.2460 & HR-ESI-MS: $360.2533[\mathrm{M}+\mathrm{H}]^{+}$ & Periconia sp. F-31 & Annona muricata & Leaves & [49] \\
\hline & periconiasin F (51) & $\mathrm{C}_{22} \mathrm{H}_{33} \mathrm{NO}_{3}$ & 359.2460 & HR-ESI-MS: $360.2533[\mathrm{M}+\mathrm{H}]^{+}$ & Periconia sp. F-31 & Annona muricata & Leaves & [49] \\
\hline
\end{tabular}


Table 1. Cont.

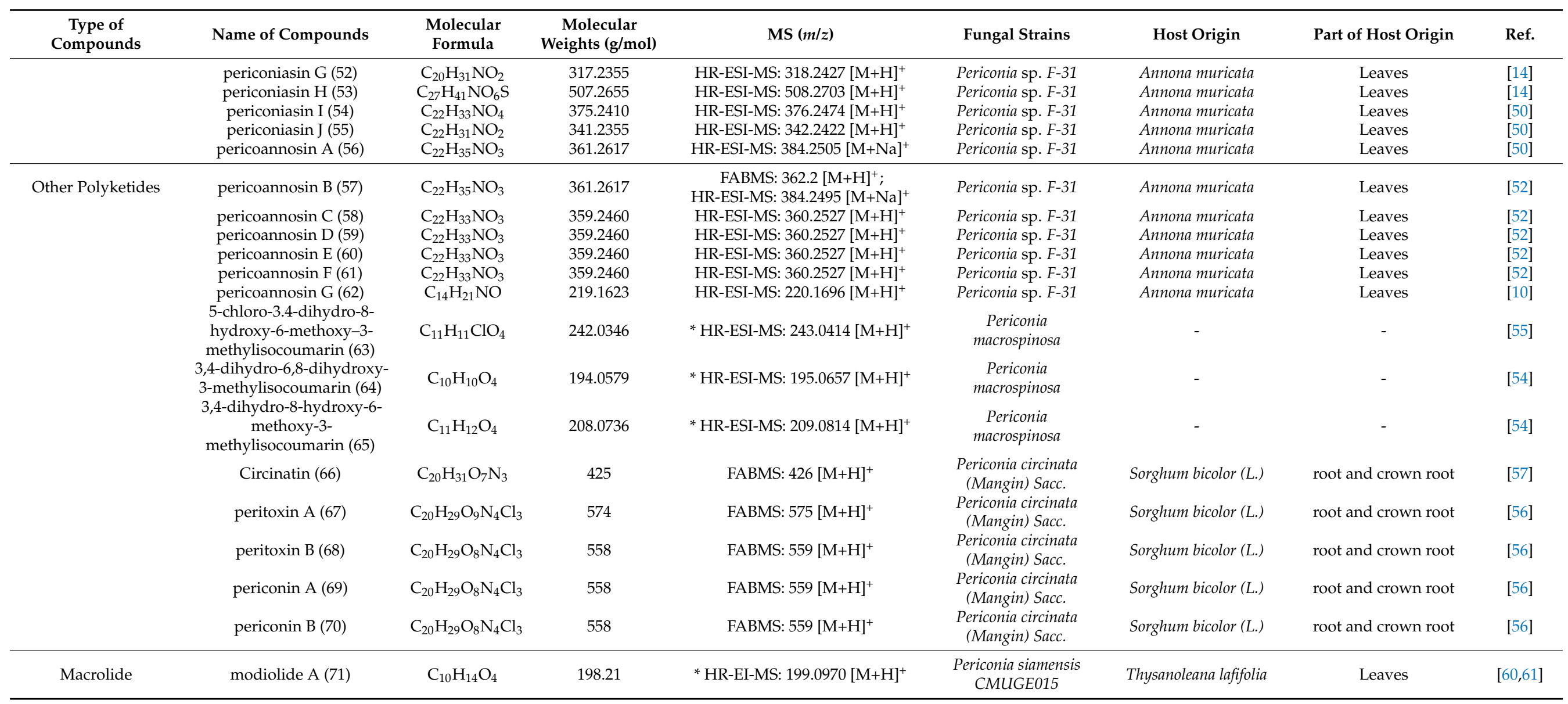


Table 1. Cont.

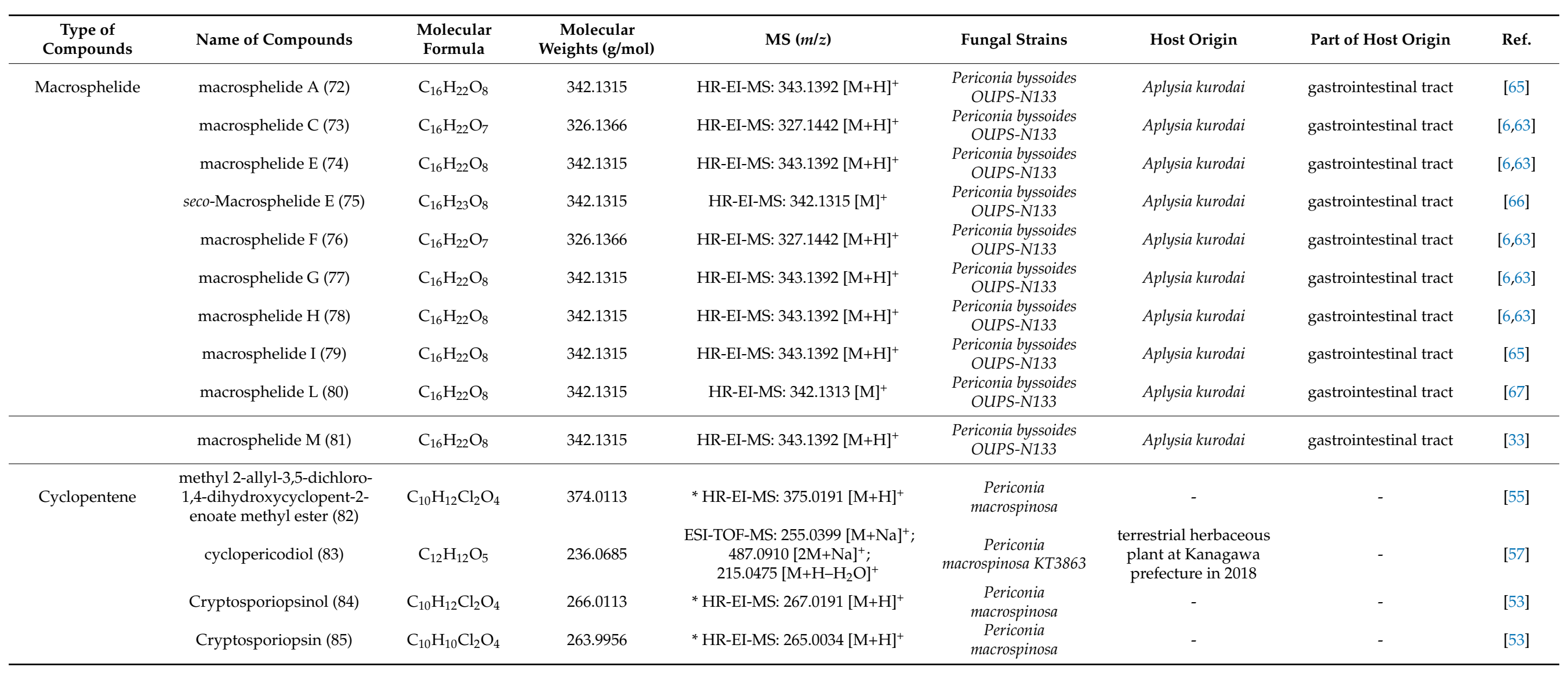


Table 1. Cont.

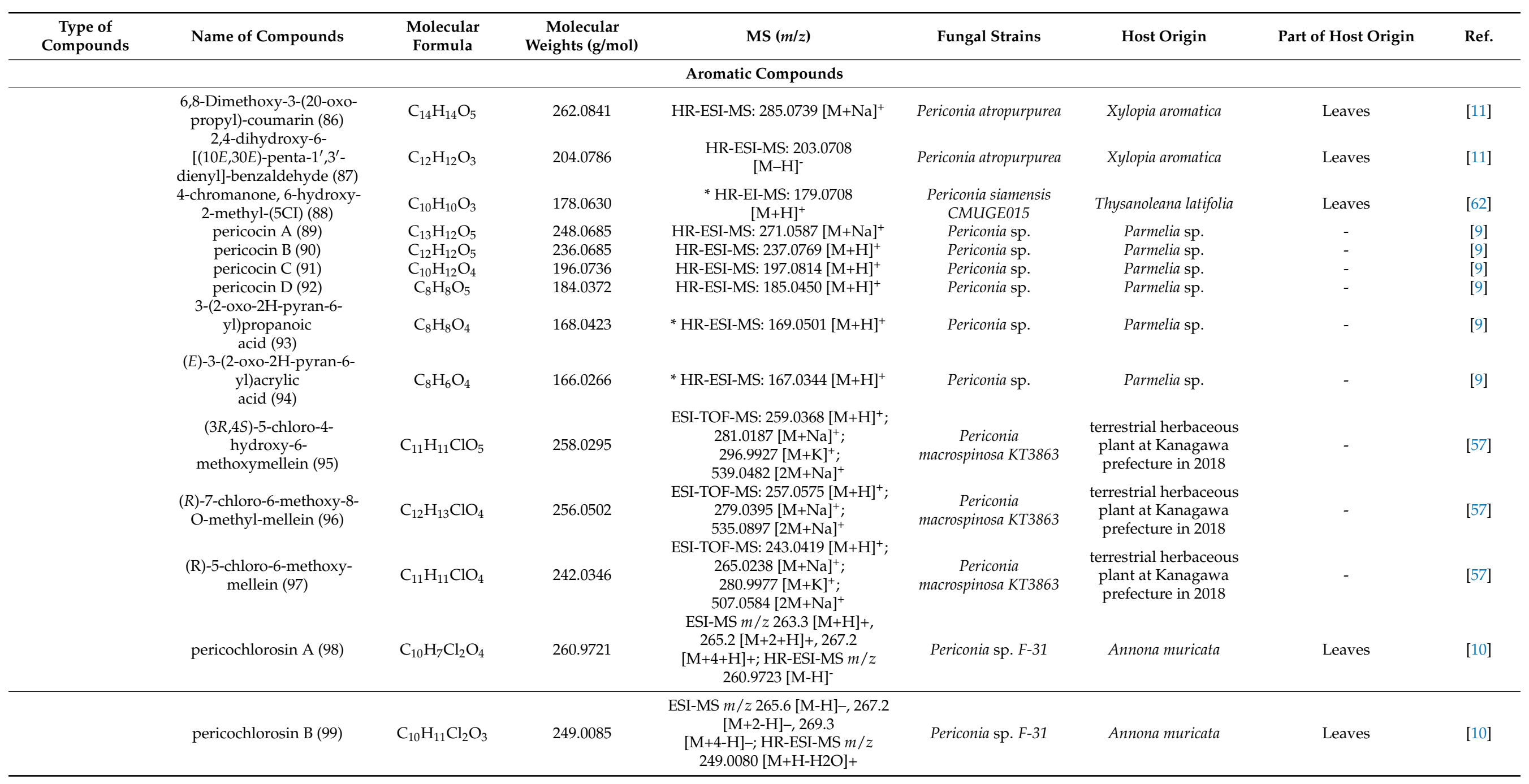


Table 1. Cont.

\begin{tabular}{|c|c|c|c|c|c|c|c|c|}
\hline \multicolumn{9}{|c|}{ CarbohydrateDerivates } \\
\hline $\begin{array}{c}\text { Type of } \\
\text { Compounds }\end{array}$ & Name of Compounds & $\begin{array}{l}\text { Molecular } \\
\text { Formula }\end{array}$ & $\begin{array}{c}\text { Molecular } \\
\text { Weights (g/mol) }\end{array}$ & $\operatorname{MS}(m / z)$ & Fungal Strains & Host Origin & Part of Host Origin & Ref. \\
\hline & pericosine A (100) & $\mathrm{C}_{8} \mathrm{H}_{11} \mathrm{ClO}_{5}$ & 222.0295 & HR-EI-MS: $223.0373[\mathrm{M}+\mathrm{H}]^{+}$ & Periconia byssoides OUPS-N133 & Aplysia kurodai & gastrointestinal tract & {$[6,66]$} \\
\hline & pericosine B (101) & $\mathrm{C}_{9} \mathrm{H}_{13} \mathrm{O}_{6}$ & 217.0712 & HR-EI-MS: $218.0790[\mathrm{M}+\mathrm{H}]^{+}$ & Periconia byssoides OUPS-N133 & Aplysia kurodai & gastrointestinal tract & {$[6,66]$} \\
\hline & pericosine C (102) & $\mathrm{C}_{9} \mathrm{H}_{14} \mathrm{O}_{6}$ & 218.0790 & HR-EI-MS: $219.0854[\mathrm{M}+\mathrm{H}]^{+}$ & Periconia byssoides OUPS-N133 & Aplysia kurodai & gastrointestinal tract & [66] \\
\hline & pericosine D (103) & $\mathrm{C}_{8} \mathrm{H}_{11} \mathrm{ClO}_{5}$ & 222.0295 & HR-EI-MS: $223.0363[\mathrm{M}+\mathrm{H}]^{+}$ & Periconia byssoides OUPS-N133 & Aplysia kurodai & gastrointestinal tract & [66] \\
\hline & pericosine E (104) & $\mathrm{C}_{16} \mathrm{H}_{21} \mathrm{ClO}_{10}$ & 408.0832 & HR-EI-MS: 409.0900 [M+H] $^{+}$ & Periconia byssoides OUPS-N133 & Aplysia kurodai & gastrointestinal tract & {$[66]$} \\
\hline
\end{tabular}


Author Contributions: A.A. wrote the manuscript and U.S. provided critical inputs. U.S. supervised the development of the work, helped in data interpretation and manuscript evaluation and acted as the corresponding author. Both authors discussed the results and contributed to the final manuscript. All authors have read and agreed to the published version of the manuscript.

Funding: This research and the APC was funded by the Doctoral Dissertation Research Grant, Ministry of Education and Culture, Indonesia, grant number 1827/UN6.3.1/LT/2020 and Academic Leadership Grant, Universitas Padjadjaran, grant number: 1959/UN6.3.1/PT.00/2021.

Acknowledgments: The authors are grateful to The Ministry of Education and Culture, Indonesia, for providing the funds for this study under the Doctoral Dissertation Research Grant, No: 1827/UN6.3.1/LT/2020, and Universitas Padjadjaran for providing Academic Leadership Grant, No: 1959/UN6.3.1/PT.00/2021.

Conflicts of Interest: The authors declare no conflict of interest.

\section{References}

1. Periconia Tode. Available online: http://www.indexfungorum.org/names/NamesRecord.asp?RecordID=9263 (accessed on 4 November 2020).

2. Liu, N.; Hongsanan, S.; Yang, J.; Bhat, D.J.; Liu, J.; Jumpathong, J.; Liu, Z. Periconia thailandica (Periconiaceae) a new species from Thailand. Phytotaxa 2017, 323, 253-263. [CrossRef]

3. Markovskaja, S.; Kačergius, A. Morphological and molecular characterization of Periconia pseudobyssoides sp. nov. and closely related P. byssoides. Mycol. Prog. 2014, 13, 291-302. [CrossRef]

4. Carmarán, C.C.; Novas, M.V. A review of Spegazzini taxa of Periconia and Sporocybe after over 115 years. Fungal Divers. 2003, 14, 67-76.

5. Leukel, R.W. Periconia circinata and its relation to Milo Disease. J. Agric. Res. 1948, 77, 201-222.

6. Numata, A.; Iritani, M.; Yamada, T.; Minoura, K.; Matsumura, E.; Yamori, T.; Tsuruo, T. Novel antitumour metabolites produced by a fungal strain from a sea hare. Tetrahedron Lett. 1997, 38, 8215-8218. [CrossRef]

7. Wu, Y.H.; Chen, G.D.; He, R.R.; Wang, C.X.; Hu, D.; Wang, G.Q.; Guo, L.D.; Yao, X.S.; Gao, H. Pericolactines A-C, a new class of diterpenoid alkaloids with unusual tetracyclic skeleton. Sci. Rep. 2015, 5, 17082. [CrossRef]

8. Wu, Y.H.; Chen, G.D.; Wang, C.X.; Hu, D.; Li, X.X.; Lian, Y.Y.; Lin, F.; Guo, L.D.; Gao, H.J. Pericoterpenoid A, a new bioactive cadinane-type sesquiterpene from Periconia sp. Asian Nat. Prod. Res. 2015, 17, 671-675. [CrossRef]

9. Wu, Y.H.; Xiao, G.K.; Chen, G.D.; Wang, C.X.; Hu, D.; Lian, Y.Y.; Lin, F.; Guo, L.D.; Yao, X.S.; Gao, H. Pericocins A-D, new bioactive compounds from Periconia sp. Nat. Prod. Commun. 2015, 10, 2127-2130. [CrossRef]

10. Liu, J.; Chen, M.; Chen, R.; Xie, K.; Chen, D.; Si, S.; Dai, J.J. Three new compounds from endophytic fungus Periconia sp. F-31. Chin. Pharm. Sci. 2020, 29, 244-251. [CrossRef]

11. Teles, H.L.; Sordi, R.; Silva, G.H.; Castro-Gamboa, I.; da Silva Bolzani, V.; Pfenning, L.H.; de Abreu, L.M.; Costa-Neto, C.M.; Young, M.C.M.; Araújo, Â.R. Aromatic compounds produced by Periconia atropurpurea, an endophytic fungus associated with Xylopia aromatica. Phytochemistry 2006, 67, 2686-2690. [CrossRef]

12. Verma, V.C.; Lobkovsky, E.; Gange, A.C.; Singh, S.K.; Prakash, S. Piperine production by endophytic fungus Periconia sp. Isolated from Piper longum L. J. Antibiot. 2011, 64, 427-431. [CrossRef]

13. Yamada, T.; Iritani, M.; Minoura, K.; Kawai, K.; Numata, A. Peribysins A-D, potent cell-adhesion inhibitors from a sea harederived culture of Periconia species. Org. Biomol. Chem. 2004, 2, 2131-2135. [CrossRef]

14. Zhang, D.; Tao, X.; Liu, J.; Chen, R.; Zhang, M.; Li, L.; Fang, X.; Yu, L.Y.; Dai, J. Periconiasin G, a new cytochalasan with unprecedented 7/6/5 tricyclic ring system from the endophytic fungus Periconia sp. Tetrahedron Lett. 2016, 57, 796-799. [CrossRef]

15. Li, J.Y.; Sidhu, R.S.; Ford, E.J.; Long, D.M.; Hess, W.M.; Strobel, G.A. The induction of taxol production in the Endophytic fungus-Periconia sp. from Torreya grandifolia. J. Ind. Microbiol. Biotechnol. 1998, 20, 259-264. [CrossRef]

16. Tanaka, K.; Hirayama, K.; Yonezawa, H.; Sato, G.; Toriyabe, A.; Kudo, H.; Hashimoto, A.; Matsumura, M.; Harada, Y.; Kurihara, Y.; et al. Revision of the Massarineae (Pleosporales, Dothideomycetes). Stud. Mycol. 2015, 82, 75-136. [CrossRef]

17. Periconia Tode, Fungi Mecklenburgenses Selecti 2: 2. 1791. Available online: https://www.mycobank.org (accessed on 4 November 2020).

18. NCBI Taxonomy Browser of Periconia. Available online: https://www.ncbi.nlm.nih.gov/Taxonomy/Browser/wwwtax.cgi? mode=Undef\&name=Periconia (accessed on 4 November 2020).

19. Wani, M.C.; Taylor, H.L.; Wall, M.E.; Coggon, P.; McPhail, A.T. Plant antitumor agents VI: The isolation and structure of taxol, a novel antilekemic and antitumor agent from Taxus brevifolia. J. Am. Chem. Soc. 1971, 2325-2327. [CrossRef]

20. Stierle, A.; Strobel, G.A.; Stierle, D. Taxol and taxane production by Taxomyces andreanae, an endophytic fungus of Pacific yew. Science 1993, 260, 214-216. [CrossRef]

21. Bach, T.J.; Rohmer, M. Isoprenoid Synthesis in Plants and Microorganisms: New Concepts and Experimental Approaches; Springer Science \& Business Media: New York, NY, USA, 2012. [CrossRef]

22. Liu, J.M.; Zhang, D.W.; Du, W.Y.; Zhang, M.; Zhao, J.L.; Chen, R.D.; Xie, K.B.; Dai, J.G. Four new monoterpenoids from an endophytic fungus Periconia sp. F-31. J. Asian Nat. Prod. Res. 2017, 19, 541-549. [CrossRef] 
23. Ge, H.L.; Zhang, D.W.; Li, L.; Xie, D.; Zou, J.H.; Si, Y.K.; Dai, J. Two new terpenoids from endophytic fungus Periconia sp. F-31. Chem. Pharm. Bull. 2011, 59, 1541-1544. [CrossRef]

24. Delfine, S.; Csiky, O.; Seufert, G.; Loreto, F. Fumigation with exogenous monoterpenes of a non-isoprenoid-emitting oak (Quercus suber, Monoterpene acquisition, translocation, and effect on the photosynthetic properties at high temperatures. New Phytol. 2000, 146, 27-36. [CrossRef]

25. Kim, S.; Shin, D.S.; Lee, T.; Oh, K.B. Periconicins, two new fusicoccane diterpenes produced by an endophytic fungus Periconia sp. with antibacterial activity. J. Nat. Prod. 2004, 67, 448-450. [CrossRef]

26. Ballio, A.; Chain, E.B.; De Leo, P.; Erlanger, B.F.; Mauri, M.; Tonolo, A. Fusicoccin: A new wilting toxin produced by Fusicoccum amygdali. Del. Nat. 1964, 203, 297. [CrossRef]

27. Muromtsev, G.S.; Voblikova, V.D.; Kobrina, N.S.; Koreneva, V.M.; Krasnopolskaya, L.M.; Sadovskaya, V.L. Occurrence of fusicoccanes in plants and fungi. J. Plant Growth Regul. 1994, 13, 39-49. [CrossRef]

28. Christianson, D.W. Unearthing the roots of the terpenome. Curr. Opin. Chem. Biol. 2008, 12, 141-150. [CrossRef] [PubMed]

29. Lesburg, C.A.; Caruthers, J.M.; Paschall, C.M.; Christianson, D.W. Managing and manipulating carbocations in biology: Terpenoid cyclase structure and mechanism. Curr. Opin. Struct. Biol. 1998, 8, 695-703. [CrossRef]

30. Xu, J.Q.; Hu, L.H. Five new eremophilane sesquiterpenes from Ligularia przewalskii. Helv. Chim. Acta 2008, 91, 951-957. [CrossRef]

31. Yamada, T.; Doi, M.; Miura, A.; Harada, W.; Hiramura, M.; Minoura, K.; Tanaka, R.; Numata, A. Absolute stereostructures of cell-adhesion inhibitors, peribysins A, E, F and G, produced by a sea hare-derived Periconia sp. J. Antibiot. 2005, 58, 185-191. [CrossRef]

32. Yamada, T.; Minoura, K.; Tanaka, R.; Numata, A. Cell-adhesion inhibitors produced by a sea hare-derived Periconia sp.: II absolute stereostructures of peribysins $\mathrm{H}$ and I. J. Antibiot. 2006, 59, 345-350. [CrossRef]

33. Yamada, T.; Minoura, K.; Tanaka, R.; Numata, A. Cell-adhesion inhibitors produced by a sea hare-derived Periconia sp. III absolute stereostructures of peribysin J and macrosphelide M. J. Antibiot. 2007, 60, 370-375. [CrossRef]

34. Athawale, P.R.; Kalmode, H.P.; Motiwala, Z.; Kulkarni, K.A.; Reddy, D.S. Overturning the peribysin family natural products isolated from Periconia byssoides OUPS-N133: Synthesis and stereochemical revision of peribysins A, B, C, F, and G. Org. Lett. 2020, 22, 3104-3109. [CrossRef]

35. Koshino, H.; Satoh, H.; Yamada, T.; Esumi, Y. Structural revision of peribysins C and D. Tetrahedron Lett. 2006, 47, 4623-4626. [CrossRef]

36. Angeles, A.R.; Waters, S.P.; Danishefsky, S.J. Total syntheses of (+) and (-) peribysin E. J. Am. Chem. Soc. 2008, 130, 13765-13770. [CrossRef]

37. Inose, K.; Tanaka, K.; Yamada, T.; Koshino, H.; Hashimoto, M.J. Isolation of peribysins O, P, and Q from Periconia macrospinosa KT3863 and configurational reinvestigation of peribysin E diacetate from Periconia byssoides OUPS-N133. Nat. Prod. 2019, 82, 911-918. [CrossRef] [PubMed]

38. Zhang, D.; Ge, H.; Zou, J.H.; Tao, X.; Chen, R.; Dai, J. Periconianone A, a new 6/6/6 carbocyclic sesquiterpenoid from endophytic fungus Periconia sp. with neural anti-inflammatory activity. Org. Lett. 2014, 16, 1410-1413. [CrossRef] [PubMed]

39. Liu, J.; Zhang, D.; Zhang, M.; Zhao, J.; Chen, R.; Wang, N.; Zhang, D.; Dai, J.J. Eremophilane sesquiterpenes from an endophytic fungus Periconia species. Nat. Prod. 2016, 79, 2229-2235. [CrossRef] [PubMed]

40. Rücker, G. Sesquiterpenes. Angew. Chem. Int. Ed. Engl. 1973, 12, 793-806. [CrossRef]

41. Cheng, A.X.; Lou, Y.G.; Mao, Y.B.; Lu, S.; Wang, L.J.; Chen, X.Y. Plant terpenoids: Biosynthesis and ecological functions. J. Integr. Plant Biol. 2007, 49, 179-186. [CrossRef]

42. Gao, W.; Chai, C.; He, Y.; Li, F.; Hao, X.; Cao, F.; Gu, L.; Liu, J.; Hu, Z.; Zhang, Y. Periconiastone A, an antibacterial ergosterol with a pentacyclo-[8.7.0.01,5.02,14.010,15] heptadecane system from Periconia sp. TJ403-rc01. Org. Lett. 2019, 21, 8469-8472. [CrossRef] [PubMed]

43. Liu, J.M.; Zhang, D.W.; Zhang, M.; Chen, R.D.; Yan, Z.; Zhao, J.Y.; Zhao, J.L.; Wang, N.; Dai, J.G. Periconones B-E, new meroterpenoids from endophytic fungus Periconia sp. Chin. Chem. Lett. 2017, 28, 248-252. [CrossRef]

44. Moraga, J.; Gomes, W.; Pinedo, C.; Cantoral, J.M.; Hanson, J.R.; Carbú, M.; Garrido, C.; Durán-Patrón, R.; Collado, I.G. The current status on secondary metabolites produced by plant pathogenic Colletotrichum species. Phytochem. Rev. 2019, 18, 215-239. [CrossRef]

45. Korman, T.P.; Ames, B.; Tsai, S.C. 1.08: Structural Enzymology of Polyketide Synthase: The Structure-Sequence-Function Correlation; Elsevier: Oxford, UK, 2010. [CrossRef]

46. Pfeifer, B.A.; Khosla, C. Biosynthesis of polyketides in heterologous hosts. Microbiol. Mol. Biol. Rev. 2001, 65, 106-118. [CrossRef]

47. Zaghouani, M.; Kunz, C.; Guédon, L.; Blanchard, F.; Nay, B. First total synthesis, structure revision, and natural history of the smallest cytochalasin: (+) Periconiasin G. Chem. Eur. J. 2016, 22, 15257-15260. [CrossRef]

48. Zhang, D.; Ge, H.; Xie, D.; Chen, R.; Zou, J.H.; Tao, X.; Dai, J. Periconiasins A-C, new cytotoxic cytochalasans with an unprecedented 9/6/5 tricyclic ring system from endophytic fungus Periconia sp. Org. Lett. 2013, 15, 1674-1677. [CrossRef]

49. Zhang, D.; Tao, X.; Chen, R.; Liu, J.; Li, L.; Fang, X.; Yu, L.; Dai, J. Pericoannosin A, a polyketide synthase-nonribosomal peptide synthetase hybrid metabolite with new carbon skeleton from the endophytic fungus Periconia sp. Org. Lett. 2015, 17, $4304-4307$. [CrossRef]

50. Liu, J.; Zhang, D.; Zhang, M.; Liu, X.; Chen, R.; Zhao, J.; Li, L.; Wang, N.; Dai, J. Periconiasins I and J, two new cytochalasans from an endophytic fungus Periconia sp. Tetrahedron Lett. 2016, 57, 5794-5797. [CrossRef] 
51. Fan, Y.; Zhang, D.; Tao, X.; Wang, Y.; Liu, J.; Li, L.; Zhao, J.; Yu, L.; He, Y.P.; Dai, J.; et al. Biosynthetic hypothesis-guided discovery and total syntheses of PKS-NRPS hybrid metabolites from endophytic fungus Periconia species. Org. Lett. 2019, 21, 1794-1798. [CrossRef]

52. Zhang, D.W.; Tao, X.Y.; Liu, J.M.; Chen, R.D.; Zhang, M.; Fang, X.M.; Yu, L.Y.; Dai, J.G. A new polyketide synthase-nonribosomal peptide synthetase hybrid metabolite from plant endophytic fungus Periconia sp. Chin. Chem. Lett. 2016, 27, 640-642. [CrossRef]

53. Giles, D.; Turner, W.B. Perkin Transactions. Chlorine-containing metabolites of Periconia macrospinosa. J. Chem. Soc. 1969, 1, 2187-2189. [CrossRef]

54. Henderson, G.B.; Hill, R.A. The biosynthesis of chlorine-containing metabolites of Periconia macrospinosa. J. Chem. Soc. 1982, 1, 3037-3039. [CrossRef]

55. Macko, V.; Stimmel, M.B.; Peeters, H.; Wolpert, T.J.; Dunkle, L.D.; Acklin, W.; Bänteli, R.; Jaun, B.; Arigoni, D. The structure of circinatin, a non-toxic metabolite from the plant pathogenic fungus Periconia circinate. Experientia 1990, 46, 1206-1209. [CrossRef]

56. Macko, V.; Stimmel, M.B.; Wolpert, T.J.; Dunkle, L.D.; Acklin, W.; Bänteli, R.; Jaun, B.; Arigoni, D. Structure of the host-specific toxins produced by the fungal pathogen Periconia circinate. Proc. Natl. Acad. Sci. USA 1992, 89, 9574-9578. [CrossRef]

57. Inose, K.; Tanaka, K.; Koshino, H.; Hashimoto, M. Cyclopericodiol and new chlorinated melleins isolated from Periconia macrospinosa KT3863. Tetrahedron 2019, 75, 130470. [CrossRef]

58. Paek, S.M.; Suh, Y.G. Synthetic studies on bioactive natural polyketides: Intramolecular nitrile oxide-olefin cycloaddition approach for construction of a macrolactone skeleton of macrosphelide B. Molecules 2011, 16, 4850-4860. [CrossRef]

59. Wińska, K.; Mączka, W.; Grabarczyk, M.; Sugimoto, K.; Matsuya, Y.; Szumny, A.; Anioł, M. A macrosphelide as the unexpected product of a Pleurotus ostreatus strain-mediated biotransformation of halolactones containing the gem-dimethylcyclohexane ring, Part 1. Molecules 2016, 21, 859. [CrossRef]

60. Bhilabutra, W.; Techowisan, T.; Peberdy, J.F.; Lumyong, S. Antimicrobial activity of bioactive compounds from Periconia siamensis CMUGE015. Res. J. Microbiol. 2007, 2, 749-755. [CrossRef]

61. Fun, H.K.; Bhilabutra, W.; Tuntiwachwuttikul, P.; Chantrapromma, S. 5,8-Dihydroxy-10-methyl-5,8,9, 10-tetrahydro-2H-oxecin-2one. Acta Crystallogr. Sect. E Struct. Rep. Online 2006, 62, 2478-2480. [CrossRef]

62. Tsuda, M.; Mugishima, T.; Komatsu, K.; Sone, T.; Tanaka, M.; Mikami, Y.; Kobayashi, J.I. Modiolides A and B, two new 10-membered macrolides from a marine-derived fungus. J. Nat. Prod. 2003, 66, 412-415. [CrossRef] [PubMed]

63. Yamada, T.; Iritani, M.; Doi, M.; Minoura, K.; Ito, T.; Numata, A. Absolute stereostructures of cell-adhesion inhibitors, macrosphelides C, E-G and I, produced by a Periconia species separated from an Aplysia sea hare. J. Chem. Soc. Perkin. Trans. 2001, 1, 3046-3053. [CrossRef]

64. Nakamura, H.; Ono, M.; Yamada, T.; Numata, A.; Akita, H. Determination of the absolute stereostructure of seco-Macrosphelide E produced by a fungal strain from a sea hare. Chem. Pharm. Bull. 2002, 50, 303-306. [CrossRef]

65. Yamada, T.; Iritani, M.; Minoura, K.; Numata, A.; Kobayashi, Y.; Wang, Y.G. Absolute stereostructures of cell adhesion inhibitors, macrosphelides H and L, from Periconia byssoides OUPS-N133. J. Antibiot. 2002, 55, 147-154. [CrossRef]

66. Yamada, T.; Iritani, M.; Ohishi, H.; Tanaka, K.; Minoura, K.; Doi, M.; Numata, A. Pericosines, antitumour metabolites from the sea hare-derived fungus Periconia byssoides: Structures and biological activities. Org. Biomol. Chem. 2007, 5, 3979-3986. [CrossRef] [PubMed]

67. Usami, Y.; Ichikawa, H.; Arimoto, M. Synthetic efforts for stereo structure determination of cytotoxic marine natural product Pericosines as metabolites of Periconia sp. from sea hare. Int. J. Mol. Sci. 2008, 9, 401-421. [CrossRef]

68. Andrus, M.B.; Shih, T.L. Synthesis of tuckolide, a new cholesterol biosynthesis inhibitor. J. Org. Chem. 1996, 61, 8780-8785. [CrossRef]

69. Shin, D.S.; Oh, M.N.; Yang, H.C.; Oh, K.B. Biological characterization of periconicins, bioactive secondary metabolites, produced by Periconia sp. OBW-15. J. Microbiol. Biotechnol. 2005, 15, 216-220.

70. Babu, D.C.; Rao, C.B.; Venkatesham, K.; Selvam, J.J.P.; Venkateswarlu, Y. Toward synthesis of carbasugars (+) gabosine C,(+) COTC,(+) pericosine B, and (+) pericosine C. Carbohydr. Res. 2014, 388, 130-137. [CrossRef]

71. Boyd, D.R.; Sharma, N.D.; Acaru, C.A.; Malone, J.F.; O’Dowd, C.R.; Allen, C.C.; Stevenson, P.J. Chemoenzymatic synthesis of carbasugars (+) pericosines A-C from diverse aromatic cis-dihydrodiol precursors. Org. Lett. 2010, 12, 2206-2209. [CrossRef]

72. Donohoe, T.J.; Blades, K.; Helliwell, M.; Waring, M.J.; Newcombe, N.J. The synthesis of (+) pericosine B. Tetrahedron Lett. 1998, 39, 8755-8758. [CrossRef]

73. Garcia Ruano, J.L.; López-Cantarero, J.; Alemparte, C. Toward the synthesis of (+) pericosine B. Phosphorus Sulfur Silicon Relat. Elem. 2005, 180, 1493-1494. [CrossRef]

74. Muni Raju, C.; Rao, J.P.; Rao, B.V. Stereoselective synthesis of (+) pericosine B and (+) pericosine C using ring closing metathesis approach. Tetrahedron Asymmetry 2012, 23, 86-93. [CrossRef]

75. Tripathi, S.; Shaikh, A.C.; Chen, C. Facile carbohydrate-based stereocontrolled divergent synthesis of (+)-pericosines A and B. Org. Biomol. Chem. 2011, 9, 7306-7308. [CrossRef]

76. Usami, Y. Synthesis of Marine-Derived Carbasugar Pericosines. In Studies in Natural Products Chemistry; Elsevier: Amsterdam, The Netherland, 2014. [CrossRef]

77. Usami, Y.; Hatsuno, C.; Yamamoto, H.; Tanabe, M.; Numata, A. Synthesis of the epimer of pericosine B from (-)-quinic acid. Chem. Pharm. Bull. 2004, 52, 1130-1133. [CrossRef] 
78. Usami, Y.; Horibe, Y.; Takaoka, I.; Ichikawa, H.; Arimot, M. First total synthesis of (-)-pericosine A from (-)-shikimic acid: Structure revision and determination of the absolute configuration of antitumor natural product pericosine A. Synlett 2006, 10, 1598-1600. [CrossRef]

79. Usami, Y.; Numata, A. Examination of the reactivity of hydroxy groups in multioxygenated cyclohexanoids: Synthetic study toward cytotoxic pericosine B. Chem. Pharm. Bull. 2004, 52, 1125-1129. [CrossRef] [PubMed]

80. Usami, Y.; Ohsugi, M.; Mizuki, K.; Ichikawa, H.; Arimoto, M. Facile and efficient synthesis of naturally occurring carbasugars (+)-Pericosines A and C. Organic Lett. 2009, 11, 2699-2701. [CrossRef] [PubMed]

81. Usami, Y.; Ohsugi, M.; Mizuki, K.; Ichikawa, H.; Arimoto, M. Synthesis of (-)-pericosine B, the antipode of the cytotoxic marine natural product. Org. Bio. Chem. 2009, 7, 315-318. [CrossRef] [PubMed]

82. Usami, Y.; Takaoka, I.; Ichikawa, H.; Horibe, Y.; Tomiyama, S.; Ohtsuka, M.; Imanishi, Y.; Arimoto, M. First total synthesis of antitumor natural product (+)-and (-)-pericosine A: Determination of absolute stereo structure. J. Org. Chem. 2007, 72, 6127-6134. [CrossRef] [PubMed]

83. Usami, Y.; Ueda, Y. Synthetic study toward antitumour natural product pericosine A. Chem. Lett. 2005, 34, 1062-1063. [CrossRef]

84. Usami, Y.; Ueda, Y. Stereoselective syntheses of diastereomers of antitumor natural product pericosine a from (-)-quinic acid. Synthesis 2007, 20, 3219-3225. [CrossRef]

85. Hayashi, M.; Kim, Y.P.; Hiraoka, H.; Natori, M.; Takamatsu, S.; Kawakubo, T.; Masuma, R.; Komiyama, K.; Omura, S. Macrosphelide, a novel inhibitor of cell-cell adhesion molecule. J. Antibiot. 1995, 48, 1435-1439. [CrossRef]

86. Kim, H.Y.; Park, E.J.; Joe, E.H.; Jou, I. Curcumin suppresses Janus kinase-STAT inflammatory signaling through activation of Src homology 2 domain-containing tyrosine phosphatase 2 in brain microglia. J. Immunol. 2003, 171, 6072-6079. [CrossRef]

87. Yang, S.; Zhang, D.; Yang, Z.; Hu, X.; Qian, S.; Liu, J.; Wilson, B.; Block, M.; Hong, J.S. Curcumin protects dopaminergic neuron against LPS induced neurotoxicity in primary rat neuron/glia culture. Neurochem. Res. 2008, 33, 2044-2053. [CrossRef] [PubMed] 